\title{
ARIOS: a database for ocean acidification assessment in the Iberian upwelling system (1976-2018)
}

\author{
Xosé Antonio Padin, Antón Velo, and Fiz F. Pérez \\ Instituto de Investigaciones Marinas, IIM-CSIC, 36208 Vigo, Spain \\ Correspondence: Xosé Antonio Padin (padin@iim.csic.es) \\ Received: 13 March 2020 - Discussion started: 24 April 2020 \\ Revised: 21 August 2020 - Accepted: 30 August 2020 - Published: 4 November 2020
}

\begin{abstract}
A data product of 17653 discrete samples from 3343 oceanographic stations combining measurements of $\mathrm{pH}$, alkalinity and other biogeochemical parameters off the northwestern Iberian Peninsula from June 1976 to September 2018 is presented in this study. The oceanography cruises funded by 24 projects were primarily carried out in the Ría de Vigo coastal inlet but also in an area ranging from the Bay of Biscay to the Portuguese coast. The robust seasonal cycles and long-term trends were only calculated along a longitudinal section, gathering data from the coastal and oceanic zone of the Iberian upwelling system. The $\mathrm{pH}$ in the surface waters of these separated regions, which were highly variable due to intense photosynthesis and the remineralization of organic matter, showed an interannual acidification ranging from -0.0012 to $-0.0039 \mathrm{yr}^{-1}$ that grew towards the coastline. This result is obtained despite the buffering capacity increasing in the coastal waters further inland as shown by the increase in alkalinity by $1.1 \pm 0.7$ and $2.6 \pm 1.0 \mu \mathrm{mol} \mathrm{kg}^{-1} \mathrm{yr}^{-1}$ in the inner and outer Ría de Vigo respectively, driven by interannual changes in the surface salinity of $0.0193 \pm 0.0056$ and $0.0426 \pm 0.016 \mathrm{psu} \mathrm{yr}^{-1}$ respectively. The loss of the vertical salinity gradient in the long-term trend in the inner ria was consistent with other significant biogeochemical changes such as a lower oxygen concentration and fertilization of the surface waters. These findings seem to be related to a growing footprint of sediment remineralization of organic matter in the surface layer of a more homogeneous water column.
\end{abstract}

Data are available at https://doi.org/10.20350/digitalCSIC/12498 (Pérez et al., 2020).

\section{Introduction}

Emissions of anthropogenic origin $\mathrm{CO}_{2}$ (fossil fuels, land use and cement manufacturing) into the atmosphere are the main cause behind the warming of the Earth due to the greenhouse effect (IPCC, 2013). Given the constant exchange of gases through the air-sea interface, the oceanic reservoir plays a key role as a sink for about $31 \%$ of anthropogenic $\mathrm{CO}_{2}$ emissions (Sabine et al., 2004), controlling the partial pressure of carbon dioxide in the atmosphere and regulating global temperatures.

The $\mathrm{CO}_{2}$ uptake by the oceans produces changes in the inorganic carbon system in spite of being partially dampened by the seawater buffering capacity. This ability of seawater to withdraw anthropogenic $\mathrm{CO}_{2}$ becomes more limited as more $\mathrm{CO}_{2}$ is absorbed, which will make it difficult to stabilize atmospheric $\mathrm{CO}_{2}$ in the future (Orr et al., 2009). The gradual absorption of atmospheric $\mathrm{CO}_{2}$ by the oceans decreases seawater $\mathrm{pH}$, causing ocean acidification, which conditions the buffering capacity of seawater and in turn the exchange of $\mathrm{CO}_{2}$ between the ocean and the atmosphere (Caldeira and Wickett, 2003; Raven et al., 2005). The Intergovernmental Oceanographic Commission of the UNESCO identified the chemical change in seawater brought about by ocean acidification as an indicator of a stressor on marine ecosystems with a negative impact on socio-economic activities such as fishing and shellfish farming. Hence, it was necessary for the oceanography community to observe and gather data about $\mathrm{pH}$ and other parameters of the marine carbon system to conduct accurate measurements of $\mathrm{pH}$ and ancillary parameters and provide data products to help a sustainable management of the marine resources. The effect of ocean acidification on marine ecosystems has stimulated impetus in 
the international community for gathering high-quality timeseries measurements of the marine inorganic carbon system (Hofmann et al., 2011; Andersson and MacKenzie, 2012; McElhany and Busch, 2013; Takeshita et al., 2015; Wahl et al., 2016) and for predicting the future evolution of the $\mathrm{pH}$ caused by climate change.

The threat for oceanic acidification of marine ecosystems is especially significant in regions like coastal upwelling areas, which are more sensitive and appear to respond faster to anthropogenic perturbations (Feely et al., 2008; Gruber et al., 2012; Lachkar, 2014; Hauri et al., 2013). These ecosystems are characteristic for their complex physical and biogeochemical interactions and for sustaining enormous biological productivity and productive fisheries (Pauly and Christensen, 1995; Haury et al., 2009). The photosynthetic activity in these regions is also an important mechanism for the seawater $\mathrm{CO}_{2}$ uptake, converting most of these areas into atmospheric $\mathrm{CO}_{2}$ sinks (Pérez et al., 1999; Cobo-Viveros et al., 2013). However, the high physical/chemical variability in short temporal and spatial scales of upwelling systems and the lack of regular sampling in these waters prevents a complete picture of the acidification of these ecosystems.

In the Iberian upwelling system, the researchers of the Instituto de Investigaciones Marinas (IIM-CSIC) since 1976 commenced accurate measurements of marine inorganic carbon system and associated parameters. As a result, a collection of $\mathrm{pH}$ observations and ancillary biogeochemical information along the Galicia coast $\left(40\right.$ and $\left.45^{\circ} \mathrm{N}, 11^{\circ} \mathrm{W}\right)$ has been gathered under the framework of different projects over the past 40 years. The current database, hereinafter called the ARIOS (Acidification in the Rías and the Iberian Continental Shelf) database, holds biogeochemical information from 3357 oceanographic stations, giving 17653 discrete samples. This unique collection is a starting point (i) for evaluating the ocean acidification in the Iberian upwelling system characterized by intense biogeochemical interactions as an observation-based analysis or (ii) for use as inputs in a coupled physical-biogeochemical model to disentangle these interactions at the ecosystem level.

\section{Data provenance}

\subsection{Data spatial coverage}

The main characteristic of the Galician coastline, located in the northwest of the Iberian Peninsula, is the Rías Baixas, four long coastal estuaries or rias $\left(>2.5 \mathrm{~km}^{3}\right)$ between 42 and $43^{\circ} \mathrm{N}$ (Fig. 1). The water exchange between the Rías Baixas and open waters is drastically affected by the coastal wind pattern as part of the Canary Current upwelling system (Wooster et al., 1976; Fraga 1981; Arístegui et al., 2004). Under the predominance of northeasterly winds (Blanton et al., 1984) during spring-summer, the surface offshore transport of surface waters leads to a rising cold, nutrient-rich, deep water mass called the Eastern North Atlantic Central

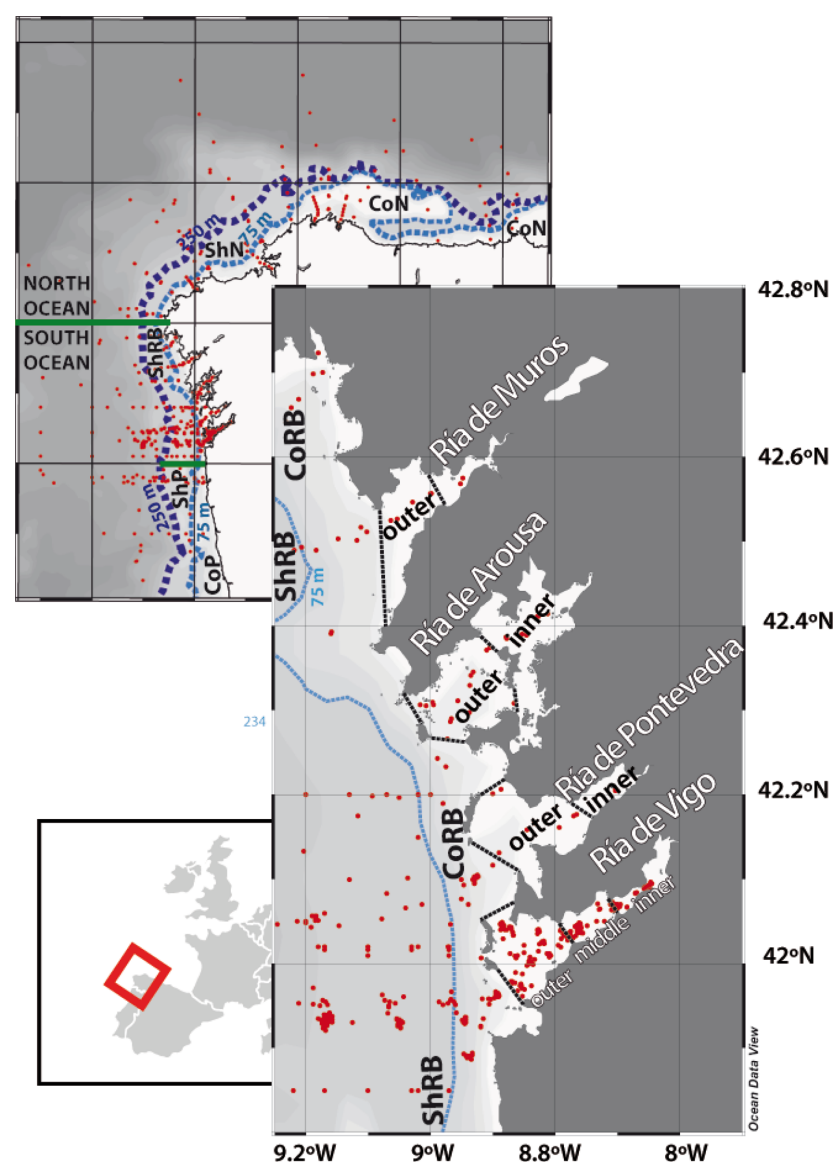

Figure 1. Map of all stations (red dots) including the geographical areas selected to classify the ARIOS database from isobath of $250 \mathrm{~m}$ (dark blue line) and $75 \mathrm{~m}$ (light blue line), latitudinal criterion (green lines), and geographical lines (black lines).

Water (ENACW) (Ríos et al., 1992). Under these conditions, the Rías Baixas act as an extension of the continental shelf (Rosón et al., 1995; Souto et al., 2003; Gilcoto et al., 2017), where upwelling filaments extending westward export primary production from the coast into the ocean (Álvarez-Salgado et al., 2001). In the opposite direction, the prevalence of northward winds (Blanton et al., 1984) moves the surface waters towards the coast, where they accumulate, sink and thus isolate the coast. This process, known as downwelling, is typical during the autumn-winter along with other characteristics such as the warm, salty waters from the Iberian Poleward Current (IPC) of subtropical origin (Fraga et al., 1982; Alvarez-Salgado et al., 2006) that flows constrained to the Iberian shelf break (Frouin et al., 1990). The runoff from local rivers also contributes to the presence of river plumes over the shelf (Otero et al., 2008). These hydrodynamic conditions, the meteorological forcings and the alternation of periods of upwelling and downwelling (Álvarez, 1999; Gago et al., 2003c; Cobo-Viveros et al., 2013) stimulate the development of intense primary production and 
high rates of recycling and downward carbon export (AlonsoPérez and Castro, 2014). The result of this biogeochemical variability in terms of air-sea $\mathrm{CO}_{2}$ exchange is that the surface waters act as a net $\mathrm{CO}_{2}$ sink that is especially intense and variable over the shelf compared to offshore or in the inner Rías Baixas (Padin et al., 2010).

Besides the short-term and seasonal variability, significant changes in the long-term scale have been reported in this region. In addition to changes such as the weakening and shortening of the upwelling events (Lemos and Sansó, 2006; Pérez et al., 2010; Alvarez-Salgado et al., 2008), the warming (González-Pola et al., 2005; Pérez et al., 2010), and changes in the composition of phytoplankton (Bode et al., 2009; Pérez et al., 2010), the acidification in the first $700 \mathrm{~m}$ for the geographical area from the Iberian Peninsula to the $20^{\circ} \mathrm{W}$ meridian and from 36 to $43^{\circ} \mathrm{N}$ has also been observed at a rate of $-0.0164 \mathrm{pH}$ units per decade (Ríos et al., 2001; Castro et al., 2009).

\subsection{Distribution of sampling}

According to the type of region under study, different areas were identified in order to classify the measurements gathered in the oceanographic cruises (Fig. 1). The latitude of $43^{\circ} \mathrm{N}$ where Cape Finisterre is located was used as the dividing line between northern and southern waters. Subsequently, a criterion of depth also split the waters to the north of $43^{\circ} \mathrm{N}$ into north oceanic (below $250 \mathrm{~m}$ ), north shelf (between 205 and $75 \mathrm{~m}$ ) and north coast ( $75 \mathrm{~m}$ to the surface). The southern shelf waters were divided by latitude $42^{\circ} \mathrm{N}$ into Portuguese and the Rías Baixas (RB) shelves, whereas the shallower waters were identified by the main rias, where three different zones were defined using longitude boundaries (outer, middle and inner) according to Gago et al. (2003c) in the Ría de Vigo and just two zones in the other rias (Ría de Pontevedra, Ría de Arousa, Ría de Muros). Southern waters between the isobath at $75 \mathrm{~m}$ and the mouth of the estuaries were identified as the Portuguese and RB coast.

The discrete measurements gathered in the ARIOS dataset were mainly found in different regions' waters around $42^{\circ} \mathrm{N}$ latitude (Figs. 1 and 2a), especially in the outer and middle areas of the Ría de Vigo, which accounted for $15 \%$ and $21 \%$ of the total measurements respectively due to the proximity to the Instituto de Investigaciones Marinas (IIM-CSIC). Most of the measurements $(85 \%)$ carried out by many of these cruises to study the coastal ecosystems concentrated on shallow waters between the seawater surface and $75 \mathrm{~m}$ in depth (Fig. 2b). Although waters below $4900 \mathrm{~m}$ depth were also sampled, observations below $900 \mathrm{~m}$ only account for $1 \%$ of the ARIOS database.

The observations made over more than 40 years in every region of the ARIOS database were irregular on both an interannual and seasonal scale (Fig. 2a). The period of most sampling activity was the 1980s and 1990s, whereas samples were especially scarce in the early 2010s. On a seasonal scale, summer and autumn were the preferred seasons to address the different research purposes, with $37 \%$ and $36 \%$ of the total samples respectively. The observations taken during less favourable winter conditions, especially aboard the coastal vessels usually available, only accounted for the $10 \%$ of the ARIOS database.

\subsection{Data sources}

The ARIOS database is a compilation of biogeochemical properties with discrete measurements of temperature, salinity, oxygen, nutrients, alkalinity, $\mathrm{pH}$ and chlorophyll that were sampled in waters off the northwest of the Iberian Peninsula from 1976 to 2018 and measured by IIM-CSIC (Table 1). This data collection is part of the research by 24 projects and oceanographic cruises conducted in response to different aims. The different sampling strategies built up an irregular biogeochemical database whose particular frequency and spatial coverage is shown in Fig. 2.

The contribution to the ARIOS database from the oceanographic cruises and projects over the different decades is described below.

\subsubsection{Cruises in the 1970s and 1980s}

The first three cruises were carried out over three periods (1976, 1981-1983 and 1983-1984), sampling the Ría de Vigo. These cruises were designed to provide environmental information (upwelling events, estuarine circulation, continental inputs, etc.) for research into the biology of some fish species. They measured identical parameters in the Vigo estuary but at different stations and frequency.

In the summer of 1984, the Galicia VIII cruise studied the summer upwelling events occurring on the contact front between the two ENACW water masses off Cape Finisterre from short sections perpendicular to the Galician coast with 85 stations offshore and 35 stations over the shelf. This cruise marked a milestone in the oceanographic research of IIMCSIC because it was the first time that the parameters of the carbon system were measured on board in offshore waters. Moreover, measurements of a particular station on the shelf break with a bottom depth of $600 \mathrm{~m}$ were taken every $2 \mathrm{~d}$ for a month, including $2 \mathrm{~d}$ continuous samplings.

Two years later, the Ría de Vigo 1986 sampled along the main axis of the Ría de Vigo in seven monthly repetitions during the first half of the year in which the primary production and the organic matter exchange between the estuary and the shelf was studied in relation to the hydrographic regime. Shortly afterwards, the same topic was also researched by the Galicia IX project in September and October 1986 from 145 stations, 50 of which were coastal and 80 located in ocean waters (Prego et al., 1990).

The following year, the 1987 Provigo project (Nogueira et al., 1997) initiated a periodic study from a fixed site $\left(42^{\circ} 14.5^{\prime} \mathrm{N}, 8^{\circ} 45.8^{\prime} \mathrm{W}\right)$ located in the main channel in the 

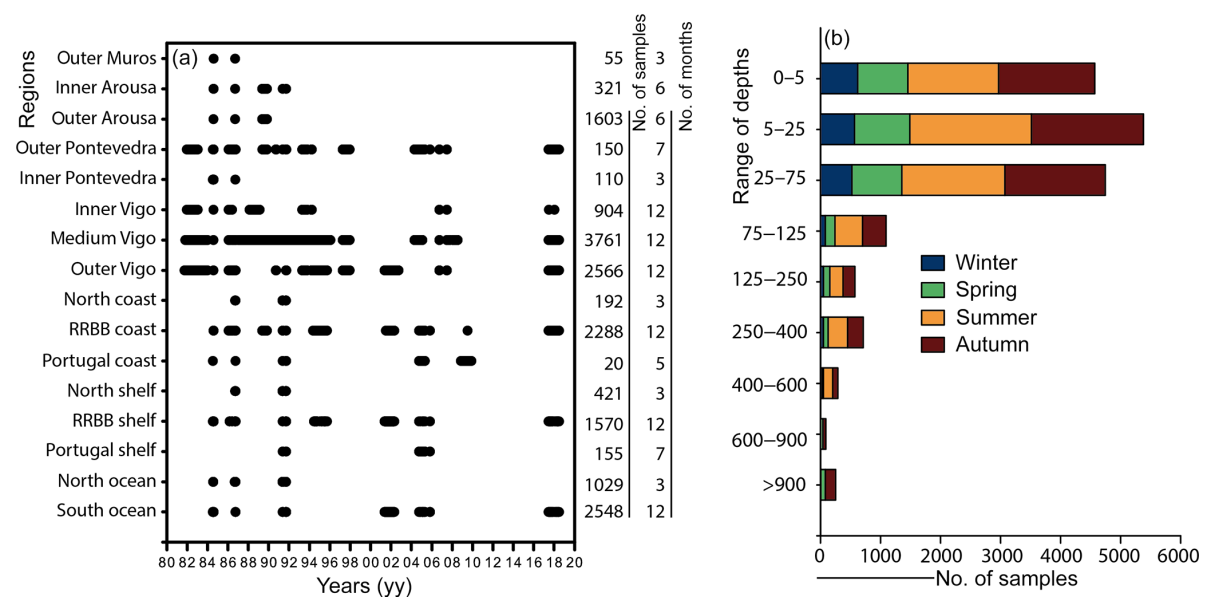

Figure 2. (a) Temporal distribution of the observations in the geographical boxes included in the ARIOS dataset. (b) Seasonal distribution of the measurements in relation to depth.

middle zone of the Ría de Vigo. This oceanographic station was selected as suitable for evaluating the main processes that occur in the inner ria associated with external forcing changes (Rios, 1992; Figueiras et al., 1994). Although the Provigo project finished in 1996, the fixed station was repeatedly included in subsequent cruises. An example of the subsequent sampling repetition of this station occurred the following year when one of the three stations in the Vigo estuary in the Luna 1988 project (Fraga et al., 1992) took a sample every 2 weeks to study the environmental control over the phytoplankton populations throughout an annual cycle (February 1988-February 1989).

At the end of the 1980s, the carbon system monitoring by the IIM-CSIC was extended to the Ría de Arousa throughout 1989 (Álvarez-Salgado et al., 1993; Perez et al., 2000) in order to learn the effect of upwelling on the water circulation pattern, community production, and the fluxes and net budgets of biogenic constituents in this ria with the highest mussel production in Europe. For 5 months, 11 stations' samples were repeated twice a week in the ria that is the most productive, housing intense cultivation of mussels on rafts (Blanton et al., 1984).

\subsubsection{Cruises of the 1990s}

In the first half of this decade, studying the phytoplankton communities was the oceanographic cruises' most relevant aim, concentrating particularly on harmful algae blooms. The hydrodynamic and biogeochemical conditions controlling the growth, development and migration of the phytoplankton were analysed both in the interior of the estuary and on the continental shelf.

For 5d in September, the 1990 Ría de Vigo cruise (Figueiras et al., 1994) sampled five stations distributed along the longitudinal axis of the ria and one at the northern mouth. The next year, the cruise Galicia XI was carried out in May, sampling at 39 stations along eight transects perpendicular to the coastline; and Galicia XII (Alvarez-Salgado et al., 1998, 2002, 2003; Castro et al., 1994) was carried out in September, sampling at 37 oceanic stations and 7 coastal stations.

The Ría de Vigo cruise in 1993-1994 (Miguez et al., 2001), with four stations using 24 repetitions with a CTDSBE25, investigated the hydrodynamic and biogeochemical effect on the evolution of phytoplankton communities in the Ría de Vigo. Six samples were taken in approximately 2 weeks corresponding to two different periods (27 September-8 October 1993 and 6-24 March 1994).

Ría de Vigo 1994-1995 (Alvarez et al., 1999; Doval et al., 1998, 1997a, b) and Ría de Vigo 1997 (Gago et al., 2003ac) were two cruises that took place in the second half of the decade. These campaigns' objective was no longer the ecology of the plankton but the factors behind the variation of the carbon pools during the upwelling and downwelling events along the central axis of the Ría de Vigo. During the 1997 cruises on board the RV Mytilus, a systematic observation of the $p \mathrm{CO}_{2}$ was carried out for the first time in Spanish coastal waters, using an autonomous continuous system with additional measurements of temperature, salinity and chlorophyll.

\subsubsection{Cruises in the 2000s and recent years}

After a period of poor sampling at the end of 1990s, the first decade of the 21st century gave new impetus to biogeochemical monitoring of Galician waters. As shown below, several projects dealt with various objectives, focussing on particular issues in the dynamics of these waters:

The DYBAGA project (Galician Platform's Annual Dynamics and Biochemistry: short-scale variation) (ÁlvarezSalgado et al., 2006; Castro et al., 2006; Nieto-Cid et al., 2004) analysed the phenomena of upwelling and downwelling in the Galician shelf opposite the Ría de Vigo weekly 
Table 1. Discrete measurements of projects gathered in the ARIOS database and associated information including dates, the principal investigator (PI), sample number (\#), the number of days between the start and the end of sampling period (\#d), measured parameters, link to data repository and the sampled geographical area.

\begin{tabular}{|c|c|c|c|c|c|c|c|c|c|c|c|c|c|c|}
\hline EXPOCODE & Project & Date & PI & \# & $\# \mathrm{~d}$ & CTD & $\mathrm{O}_{2}$ & Nut & $\mathrm{pH}$ & Alk & $\mathrm{Chl} a$ & CRM & Data Repository & Regions \\
\hline 29LP19761026 & Ría Vigo 1977 & $1976-10-26$ & Fernando Fraga & 135 & 413 & $\mathrm{~N}$ & $\mathrm{~N}$ & $\mathrm{Y}^{*}$ & $\mathrm{Y}^{\mathrm{O}}$ & $\mathrm{N}$ & $\mathrm{N}$ & $\mathrm{N}$ & https://doi.org/10.20350/digitalCSIC/9917 & $\mathrm{Co}^{\mathrm{RB}}$ \\
\hline 29LP19810929 & Ría Vigo 1981-83 & 1981-09-29 & Fernando Fraga & 748 & 472 & $\mathrm{~N}$ & $\mathrm{Y}^{*}$ & $\mathrm{Y}^{*}$ & $\mathrm{Y}^{\mathrm{O}}$ & Y & $\mathrm{N}$ & $\mathrm{N}$ & https://doi.org/10.20350/digitalCSIC/9918 & $\mathrm{RV}^{\mathrm{O}, \mathrm{M}, \mathrm{I}}$ \\
\hline 29LP19830215 & Ría Vigo $1983-84$ & $1983-02-15$ & Fernando Fraga & 312 & 322 & $\mathrm{~N}$ & $\mathrm{Y}^{*}$ & $\mathrm{Y}^{*}$ & $\mathrm{Y}^{\mathrm{O}}$ & $\mathrm{Y}$ & $\mathrm{N}$ & $\mathrm{N}$ & https://doi.org/10.20350/digitalCSIC/9919 & $\mathrm{RV}^{\mathrm{O}, \mathrm{M}}$ \\
\hline 29GD19840711 & GALICIA-VIII & $1984-07-11$ & Fernando Fraga & 1865 & 28 & $\mathrm{~N}$ & $\mathrm{Y}$ & $\mathrm{Y}$ & $\mathrm{Y}^{\mathrm{O}}$ & $\mathrm{Y}$ & $\mathrm{Y}$ & $\mathrm{N}$ & https://doi.org/10.20350/digitalCSIC/9908 & $\begin{array}{l}\mathrm{O}^{\mathrm{N}, \mathrm{S}}, \mathrm{Sh}^{\mathrm{RB}}, \\
\mathrm{Co}^{\mathrm{P}, \mathrm{RB}}, \\
\mathrm{RV}^{\mathrm{O}, \mathrm{M}, \mathrm{I}}, \\
\mathrm{RA}^{\mathrm{O}, \mathrm{I}}, \mathrm{RP}^{\mathrm{O}, \mathrm{I}}, \\
\mathrm{RM}\end{array}$ \\
\hline 29GD19860121 & Ría Vigo 1986 & 1986-01-21 & Fernando Fraga & 332 & 203 & $\mathrm{~N}$ & Y & Y & $\mathrm{Y}^{\mathrm{O}}$ & Y & Y & $\mathrm{N}$ & https://doi.org/10.20350/digitalCSIC/9910 & $\begin{array}{l}\mathrm{Sh}^{\mathrm{RB}}, \mathrm{Co}^{\mathrm{RB}}, \\
\mathrm{RV}^{\mathrm{O}, \mathrm{M}, \mathrm{I}}\end{array}$ \\
\hline 29GD19860904 & GALICIA-IX & 1986-09-04 & Fernando Fraga & 1640 & 5 & $\mathrm{~N}$ & Y & Y & $\mathrm{Y}^{\mathrm{O}}$ & $\mathrm{Y}$ & $\mathrm{Y}$ & $\mathrm{N}$ & https://doi.org/10.20350/digitalCSIC/9911 & $\begin{array}{l}\mathrm{O}^{\mathrm{N}, \mathrm{S}}, \\
\mathrm{Sh}^{\mathrm{RB}, \mathrm{N}}, \\
\mathrm{Co}^{\mathrm{P}, \mathrm{RB}, \mathrm{N}}, \\
\mathrm{RV}^{\mathrm{O}, \mathrm{M}, \mathrm{I}}, \\
\mathrm{RA}^{\mathrm{O}, \mathrm{I}}, \mathrm{RP}^{\mathrm{O}, \mathrm{I}}, \\
\mathrm{RM}\end{array}$ \\
\hline 29LP19870120 & PROVIGO & $1987-01-20$ & Fiz F. Pérez & 2317 & 3290 & $\mathrm{~N}$ & Y & Y & $\mathrm{Y}^{\mathrm{O}}$ & $\mathrm{N}$ & Y & $\mathrm{N}$ & https://doi.org/10.20350/digitalCSIC/9924 & $\mathrm{RV}^{\mathrm{M}}$ \\
\hline 29LP19880212 & LUNA 88 & $1988-02-12$ & Aida F. Rios & 468 & 367 & $\mathrm{~N}$ & $\mathrm{Y}$ & $\mathrm{Y}$ & $\mathrm{Y}^{\mathrm{O}}$ & $\mathrm{Y}$ & $\mathrm{Y}$ & $\mathrm{N}$ & https://doi.org/10.20350/digitalCSIC/9907 & $\mathrm{RV}^{\mathrm{M}, \mathrm{I}}$ \\
\hline 29IN19890512 & GALICIA-X & $1989-05-12$ & Fiz F. Pérez & 3113 & 171 & $\mathrm{~N}$ & Y & $\mathrm{Y}$ & $\mathrm{Y}^{\mathrm{O}}$ & Y & $\mathrm{Y}$ & $\mathrm{N}$ & https://doi.org/10.20350/digitalCSIC/9920 & $\mathrm{Co}^{\mathrm{RB}}, \mathrm{RA}^{\mathrm{O}, \mathrm{I}}$ \\
\hline 29IN19900914 & Ría Vigo 1990 & $1990-09-14$ & $\begin{array}{l}\text { Francisco G. } \\
\text { Figueiras }\end{array}$ & 108 & 13 & $\mathrm{Y}$ & Y & Y & $\mathrm{Y}^{\mathrm{O}}$ & $\mathrm{Y}$ & $\mathrm{Y}$ & $\mathrm{N}$ & https://doi.org/10.20350/digitalCSIC/9921 & $\mathrm{RV}^{\mathrm{O}, \mathrm{M}, \mathrm{I}}$ \\
\hline 29IN19910510 & GALICIA-XI & $1991-05-10$ & Fiz F. Pérez & 327 & 4 & $\mathrm{Y}$ & Y & $\mathrm{Y}$ & $\mathrm{Y}^{\mathrm{O}}$ & $\mathrm{Y}$ & $\mathrm{Y}$ & $\mathrm{N}$ & https://doi.org/10.20350/digitalCSIC/9922 & $\begin{array}{l}\mathrm{O}^{\mathrm{N}, \mathrm{S}}, \\
\mathrm{Sh}^{\mathrm{P}, \mathrm{RB}, \mathrm{N}}, \\
\mathrm{Co}^{\mathrm{P}, \mathrm{RB}, \mathrm{N}}, \\
\mathrm{RA}^{\mathrm{O}}\end{array}$ \\
\hline 29IN19910910 & GALICIA-XII & 1991-09-10 & $\begin{array}{l}\text { Francisco G. } \\
\text { Figueiras }\end{array}$ & 663 & 10 & $\mathrm{Y}$ & Y & Y & $\mathrm{Y}^{\mathrm{O}}$ & $\mathrm{Y}$ & $\mathrm{Y}$ & $\mathrm{N}$ & https://doi.org/10.20350/digitalCSIC/9923 & $\begin{array}{l}\mathrm{O}^{\mathrm{N}, \mathrm{S}}, \\
\mathrm{Sh}^{\mathrm{P}, \mathrm{RB}, \mathrm{N}}, \\
\mathrm{Co}^{\mathrm{P}, \mathrm{RB}, \mathrm{N}}, \\
\mathrm{RV}^{\mathrm{O}, \mathrm{M}, \mathrm{I}}, \\
\mathrm{RA}^{\mathrm{O}}\end{array}$ \\
\hline 29LP19930413 & Ría Vigo 1993-94 & 1993-04-13 & $\begin{array}{l}\text { Francisco G. } \\
\text { Figueiras }\end{array}$ & 406 & 344 & $\mathrm{Y}$ & $\mathrm{Y}$ & Y & $\mathrm{Y}^{\mathrm{O}}$ & $\mathrm{Y}$ & $\mathrm{Y}$ & $\mathrm{N}$ & https://doi.org/10.20350/digitalCSIC/9927 & $\mathrm{RV}^{\mathrm{O}, \mathrm{M}, \mathrm{I}}$ \\
\hline 29JN19940505 & Ría Vigo 1994-95 & 1994-05-05 & Manuel Cabanas & 669 & 504 & $\mathrm{Y}$ & $\mathrm{Y}$ & Y & $\mathrm{Y}^{\mathrm{O}}$ & $\mathrm{Y}$ & $\mathrm{Y}$ & $\mathrm{N}$ & https://doi.org/10.20350/digitalCSIC/9926 & $\begin{array}{l}\mathrm{Sh}^{\mathrm{RB}}, \mathrm{Co}^{\mathrm{RB}}, \\
\mathrm{RV}^{\mathrm{O}}\end{array}$ \\
\hline 29MY19970407 & CIRCA-97 & 1997-04-07 & Fiz F. Pérez & 547 & 248 & $\mathrm{Y}$ & $\mathrm{Y}$ & $\mathrm{N}$ & $\mathrm{Y}^{\mathrm{O}}$ & $\mathrm{Y}$ & $\mathrm{Y}$ & $\mathrm{N}$ & https://doi.org/10.20350/digitalCSIC/9928 & $\mathrm{RV}^{\mathrm{O}, \mathrm{M}, \mathrm{I}}$ \\
\hline 29MY20010515 & DYBAGA & 2001-05-15 & Fiz F. Pérez & 1421 & 344 & $\mathrm{Y}$ & $\mathrm{Y}$ & $\mathrm{Y}^{*}$ & $\mathrm{Y}$ & $\mathrm{Y}$ & $\mathrm{Y}$ & $\mathrm{Y}$ & https://doi.org/10.20350/digitalCSIC/9929 & $\begin{array}{l}\mathrm{Sh}^{\mathrm{P}, \mathrm{RB}}, \\
\mathrm{Co}^{\mathrm{RB}}, \mathrm{RV}^{\mathrm{O}}\end{array}$ \\
\hline 29MY20010702 & REMODA & 2001-07-02 & $\begin{array}{l}\text { Xosé Antón } \\
\text { Alvarez-Salgado }\end{array}$ & 203 & 451 & $\mathrm{Y}$ & $\mathrm{Y}$ & $\mathrm{Y}^{*}$ & $\mathrm{Y}$ & $\mathrm{Y}$ & $\mathrm{Y}$ & $\mathrm{Y}$ & https://doi.org/10.20350/digitalCSIC/9930 & $\mathrm{RV}^{\mathrm{O}}$ \\
\hline 29MY20040419 & FLUVBE & 2004-04-19 & $\begin{array}{l}\text { Carmen G. } \\
\text { Castro }\end{array}$ & 187 & 283 & $\mathrm{Y}$ & Y & $\mathrm{Y}^{*}$ & $\mathrm{Y}$ & $\mathrm{Y}$ & $\mathrm{Y}$ & $\mathrm{Y}$ & to be submitted & $\mathrm{RV}^{\mathrm{M}, \mathrm{I}}$ \\
\hline $29 \mathrm{CS} 20041004$ & ZOTRACOS & 2004-10-04 & Manuel Cabanas & 371 & 389 & $\mathrm{Y}$ & $\mathrm{Y}$ & $\mathrm{Y}$ & $\mathrm{Y}$ & $\mathrm{Y}$ & $\mathrm{Y}$ & $\mathrm{Y}$ & https://doi.org/10.20350/digitalCSIC/9932 & $\begin{array}{l}\mathrm{Sh}^{\mathrm{P}, \mathrm{RB}}, \\
\mathrm{Co}^{\mathrm{P}, \mathrm{RB}}, \mathrm{RP}^{\mathrm{O}}\end{array}$ \\
\hline 29MY20060926 & CRÍA & 2006-09-26 & Eric D. Barton & 197 & 275 & $\mathrm{Y}$ & $\mathrm{Y}$ & $\mathrm{Y}^{*}$ & $\mathrm{Y}$ & $\mathrm{Y}$ & $\mathrm{Y}$ & $\mathrm{Y}$ & https://doi.org/10.20350/digitalCSIC/9931 & $\mathrm{RV}^{\mathrm{O}, \mathrm{M}, \mathrm{I}}$ \\
\hline 29MY20070917 & RAFTING & 2007-09-17 & $\begin{array}{l}\text { Carmen G. } \\
\text { Castro }\end{array}$ & 287 & 301 & $\mathrm{Y}$ & $\mathrm{Y}$ & $\mathrm{Y}^{*}$ & $\mathrm{Y}$ & $\mathrm{Y}$ & $\mathrm{Y}$ & $\mathrm{Y}$ & to be submitted & $\mathrm{RV}^{\mathrm{M}}$ \\
\hline 29MY20081105 & LOCO & 2008-11-05 & $\begin{array}{l}\text { Xosé Antón } \\
\text { Alvarez-Salgado }\end{array}$ & 72 & 378 & Y & $\mathrm{Y}$ & $\mathrm{Y}$ & $\mathrm{Y}$ & $\mathrm{Y}$ & $\mathrm{Y}$ & $\mathrm{Y}$ & https://doi.org/10.20350/digitalCSIC/9936 & $\mathrm{Co}^{\mathrm{RB}}$ \\
\hline 29AH20090710 & CAIBEX-I & 2009-07-10 & Eric D. Barton & 191 & 11 & $\mathrm{Y}$ & $\mathrm{Y}$ & $\mathrm{Y}$ & $\mathrm{Y}$ & $\mathrm{Y}$ & $\mathrm{Y}$ & $\mathrm{Y}$ & https://doi.org/10.20350/digitalCSIC/9934 & $\mathrm{Co}^{\mathrm{P}, \mathrm{RB}}$ \\
\hline 29MY20170609 & ARIOS & 2017-06-09 & Fiz F. Pérez & 1114 & 382 & $\mathrm{Y}$ & $\mathrm{Y}$ & $\mathrm{Y}^{*}$ & $\mathrm{Y}$ & $\mathrm{Y}$ & $\mathrm{Y}$ & $\mathrm{Y}$ & https://doi.org/10.20350/digitalCSIC/9963 & $\begin{array}{l}\mathrm{Sh}^{\mathrm{P}, \mathrm{RB}}, \\
\mathrm{Co}^{\mathrm{RB}} \\
\mathrm{RV}^{\mathrm{O}, \mathrm{M}, \mathrm{I}}\end{array}$ \\
\hline
\end{tabular}

and their impact on the different biogeochemical and carbon system variables including organic dissolved matter. Three stations were sampled weekly from May 2001 to April 2002 between the shelf break ( $1200 \mathrm{~m}$ depth) to the middle of the Ría de Vigo (45 m depth).

The REMODA (Reactivity of dissolved organic matter in a coastal upwelling system) (Álvarez-Salgado et al., 2005; Piedracoba et al., 2005; Nieto-Cid et al., 2006) project concentrated on learning the origin and destination of dissolved organic matter in the Ría de Vigo as well. Three stations along the main axis of the Ría de Vigo, including the fixed station as the central one, took samples with short (3-4d) and seasonal timescales.
The FLUVBE project (Coupling of benthic and pelagic fluxes in the Ría de Vigo) added to knowledge about the productivity and the benthic fluxes of oxygen and inorganic nutrients in the Ría de Vigo from 16 oceanographic surveys with four stations between April 2004 and January 2005.

The ZOTRACOS project studied the biogeochemical and hydrodynamic characterization of the coastal transition zone in NW Spain during the downwelling period (Teira et al., 2009).

The CRIA (Circulation in a RIA) (Barton et al., 2019) project examined the layout of the two-layer circulation and propagation of upwelled and downwelled waters in order to estimate the flushing and vertical velocities in the Ría de Vigo in repeated hydrographic surveys between Septem- 
ber 2006 and June 2007 (Barton et al., 2015, 2016; AlonsoPerez and Castro, 2014; Alonso-Perez et al., 2010, 2015).

The RAFTING project (Impact of mussel raft cultivation on the benthic-pelagic coupling in a Galician Ría) (Froján et al., 2018, 2016, 2014) assessed for the first time how mussel cultivation influences the quality of particular organic carbon fluxes in the Ría de Vigo. Over the four seasons, two stations were visited every 2 to $3 \mathrm{~d}$ during each period, meaning 24 oceanographic cruises in 2007 and 2008.

The CAIBEX (Continental shelf-ocean exchanges in the marine ecosystem of the Canary Islands-Iberian Peninsula) (Villacieros-Robineau et al., 2019) project compared the dynamics and biogeochemical activity between the coastal zone and the adjacent ocean in the study zone during the summer upwelling events. As part of the CAIBEX project, a mooring at the LOCO (Laboratory of Ocean and Coastal Observation) (Zuñiga et al., 2016, 2017) site located on the continental shelf was deployed and visited monthly for 1 year to monitor the vertical profiles of biogeochemical variables.

After these projects were completed in 2009, new measurements were not provided until 2018. The aim of the ARIOS project (Acidification in the Rías and the Iberian Continental Shelf) was to evaluate the impact of ocean acidification and learn about potential impacts on the mussels and their adaptation (Lassoued et al., 2019) to the new climate change.

\subsection{Methods}

To assess of the level of acidification in the ocean adjacent to the Galician coast, variables of the carbon system ( $\mathrm{pH}$ and alkalinity), nutrient concentration, dissolved oxygen, chlorophyll $a$, salinity and temperature were measured in each cruise. The variables measured in each oceanographic cruise gathered in the ARIOS dataset are shown in Table 1. The main changes in the materials and methods throughout these years are detailed below.

\subsubsection{Temperature and salinity measurements}

Temperatures from 1976 to 1984 were measured using a Wallace and Tiernan bathythermograph. Reversing thermometers that had a precision of $0.02^{\circ} \mathrm{C}$ were used, attached to the water samplers between 1984 and 1990, correcting the temperature between the protected and unprotected thermometers according to Anderson (1974). During those years, the depth was calculated from the thermometric readings, rounding the result off to the nearest ten. After 1990, different models of CTD instruments that measured the seawater temperature with a precision of $0.002{ }^{\circ} \mathrm{C}$ were used to obtain the thermohaline profile.

The first measurements of salinity were determined with a Plessey Environmental Systems 6230N inductive salinometer calibrated with normal IAPSO water and calculated from the equations given in the NIO and UNESCO International
Oceanographic Tables (1981). The precision of these salinity measurements was $0.005 \mathrm{psu}$. After using this equipment, the salinity was determined with an Autosal 8400A inductive salinometer calibrated with normal IAPSO water, whose estimated analytical error was 0.003 , using the equation of practical salinity given by UNESCO (1981). CTDs began to be used in 1990 to record the vertical salinity profiles, calibrated using the salinity samples, whose possible deviations in the measurements were estimated from the discrete measurements from the Autosal salinometer.

\subsection{2 pH measurements}

The $\mathrm{pH}$ measurements were originally taken with a Metrohm $\mathrm{E}-510 \mathrm{pH}$ meter with a glass electrode and a $\mathrm{Ag} / \mathrm{ClAg}$ reference one calibrated with 7.413 NBS buffer. All pH values were converted to values at $15^{\circ} \mathrm{C}$ using the temperature correction from the Buch and Nynas tables published by Barnes (1959). In 1984, the method was modified and the temperature normalization was carried out following Pérez and Fraga (1987b). Two years later, the measurement equipment was the Metrohm E-654 pH meter with an Orion 8104 Ross combined glass electrode, with the $\mathrm{pH}$ converted to the SWS scale using the hydrogen activity coefficient given by Mehrbach et al. (1973) at $25^{\circ} \mathrm{C}$ with the parameterization given by Pérez and Fraga (1987b). The error in this potentiometric method was 0.010 . In 2001, the seawater $\mathrm{pH}$ measurements were determined with a spectrophotometric method following Clayton and Byrne (1993), subsequently adding 0.0047 to the $\mathrm{pH}$ value according to DelValls and Dickson (1998). The precision of the spectrophotometric measurements was $0.003 \mathrm{pH}$ units.

The $\mathrm{pH}$ values were reported on the total $\mathrm{pH}$ scale at $0 \mathrm{dbar}$ of pressure and both at $25^{\circ} \mathrm{C}$ and in situ temperature $\left(\mathrm{pH}_{T}\right)$ following the same procedure of GLODAP v2 (Olsen et al., 2019). A total of 12220 measurements of $\mathrm{pH}$ on the NBS scale were converted to the total scale using CO2SYS (Lewis and Wallace, 1998) for MATLAB (van Heuven et al., 2011) with $\mathrm{pH}$ and total alkalinity as inputs. The conversion was conducted with the carbonate dissociation constants of Lueker et al. (2000) and the borate-to-salinity ratio of Uppström (1974). Whenever total alkalinity data were missing, these values were approximated as 66 times salinity that is the mean ratio between the total alkalinity and the salinity of every in situ measurement compiled in the ARIOS database. Data for phosphate and silicate are also needed, and, whenever missing, a constant value of $10 \mu \mathrm{mol} \mathrm{kg}^{-1}$ for silicate and a constant value of $1 \mu \mathrm{mol} \mathrm{kg}{ }^{-1}$ for phosphate were used. These approximations were tested on 8296 samples with complete biogeochemical information showing a bias of less than $0.0004 \mathrm{pH}$ units for $99.95 \%$ of the samples. 


\subsubsection{Alkalinity measurements}

The seawater alkalinity was measured for the first time in 1981 by potentiometric titration with $\mathrm{HCl} 0.1 \mathrm{M}$ at a final pH 4.44 following Pérez and Fraga (1987a) with an analytical error of $2 \mu \mathrm{mol} \mathrm{kg} \mathrm{kg}^{-1}$ and a precision of $0.1 \%$. Sodium tetraborate decahydrate (Borax, $\mathrm{Na}_{2} \mathrm{~B}_{4} \mathrm{O}_{7} 10 \mathrm{H}_{2} 0$, Merck PA) was used for standardizing the $\mathrm{HCl}(0.13 \mathrm{M})$. The $\mathrm{pH}$ measurements were carried out with a combined glass electrode (Metrohm E-121) with $\mathrm{Ag} / \mathrm{AgCl}$ (KC1 3M) as the reference. The $\mathrm{pH}$ was calibrated using the NBS buffers assuming the theoretical slope. As of 2001, the accuracy of alkalinity measurements was determined using samples of certified reference material (CRM) provided by Andrew Dickson, University of California, improving the precision to $\pm 1.4 \mathrm{~mol} \mathrm{~kg}^{-1}$ and an accuracy of $<0.1 \%$ recently established by Ríos and Pérez (1999) from cross-calculation with measured certified reference materials (Dickson et al., 2007).

\subsubsection{Nutrient measurements}

Except for the Galicia cruises (Table 1), in which nutrient samples were analysed on board, samples were kept in the dark and cold $\left(4^{\circ} \mathrm{C}\right)$ after collection for further analyses in the shore-based laboratory. Nutrient concentration was determined by a flow-segmented autoanalyser (Technicon AAII and Alpkem after 1995) as described in Strickland and Parsons (1972), with the particularity that the reduction of nitrate to nitrite with $\mathrm{Cd}$ column was done using a citrate buffer according to Mouriño and Fraga's modification (1985). Phosphates and silicates were measured following Grasshoff (1983) and ammonium as described by Grasshoff and Johannsen (1972). This method was maintained in the subsequent cruises, achieving a precision of $0.02 \mu \mathrm{mol} \mathrm{kg}^{-1}$ for nitrite, $0.1 \mu \mathrm{mol} \mathrm{kg}{ }^{-1}$ for nitrate, $0.05 \mu \mathrm{mol} \mathrm{kg}{ }^{-1}$ for ammonium and silicate, and $0.01 \mu \mathrm{mol} \mathrm{kg}{ }^{-1}$ for phosphate.

\subsubsection{Oxygen measurements}

The dissolved oxygen was determined via the Winkler titration method for the first time in 1981 following the procedure published later by Culberson et al. (1991). The oxygen concentration in the samples in this method was fixed with $\mathrm{MnCl}_{2}$ and $\mathrm{NaOH} / \mathrm{NaI}$, which were kept in the dark until analysis in the laboratory $12-24 \mathrm{~h}$ later. The measurements were made by titration of iodine with thiosulfate using an automatic titrator. During the 1980s and early 1990s, the titration was carried out with Metrohm instruments (E-425 or E473 ), which had an analytical error of $1 \mu \mathrm{mol} \mathrm{kg}{ }^{-1}$. The oxygen concentration after 1997 was estimated using a Titrino 720 (Metrohm) analyser with an accuracy of $0.5 \mu \mathrm{mol} \mathrm{kg}{ }^{-1}$.

\subsubsection{Chlorophyll measurements}

The chlorophyll- $a$ values were measured following SCORUNESCO (1966) using a $6 \mathrm{~cm}$ diameter Schleicher and Scholl 602eh filter covered with magnesium carbonate. The absorption was measured in $1 \mathrm{~cm}$ optical path cuvettes using a Beckman DU spectrophotometer. In 1984, discrete water samples of the chlorophyll- $a$ samples were filtered through Whatman GF/F filters of $2.5 \mathrm{~cm}$, which were preferred from then on, and measured fluorometrically following Strickland and Parsons (1972) without correction for concentration by phaeophytes. The fluorescence readings were carried out with a Turner Designs 10000 R fluorometer (Yentsh and Menzel, 1963) obtaining a precision of $0.05 \mathrm{~g} \mathrm{~L}^{-1}$.

\subsubsection{Quality control}

Every cruise gathered in Table 1 passed first quality control (QC1) to ensure truly confident results. The GO-SHIP software for quality control of hydrographic data (Velo et al., 2019) that compiles several QC1 procedures was applied to the ARIOS dataset. That procedures consist in reviewing the property profiles and property-property plots generated by that application, adequate for each variable. A quality control flag value following the recommendations from WOCE bottle data flagging quality codes was assigned to each measurement available from the repository sites (Table 1). This method was preferred over applying a very stringent flagging process because it is difficult to rule out some extreme values associated with low salinities or that could be supported by the high variability of an ecosystem characterized by an intense biological activity. Nutrients and chlorophyll with values inferior to the precision were flag $=2$. Some very low $\mathrm{pH}$ values associated with very low salinity waters were flagged as doubtful.

The ARIOS database includes the cruise corrections for $\mathrm{pH}$ data of the -0.017 for the Galicia VIII cruise (29GD19840711) and +0.032 for Galicia IX cruise (29GD19860904) detected during the second level quality control of the CARINA project (Velo et al., 2010).

\section{Results}

Some of the most obvious results provided by the ARIOS database are shown below. The purpose is to describe the environmental context and the main oceanographic processes that affect the variability of these discrete measurements and offer preliminary information for future detailed biogeochemical research.

\subsection{Vertical distribution}

The vertical profile of the temperature, salinity, $\mathrm{pH}$ on total scale at in situ temperature $\left(\mathrm{pH}_{T}\right), \mathrm{NO}_{3}^{-}$and oxygen concentration in the ocean region between 41 and $43^{\circ} \mathrm{N}$ 


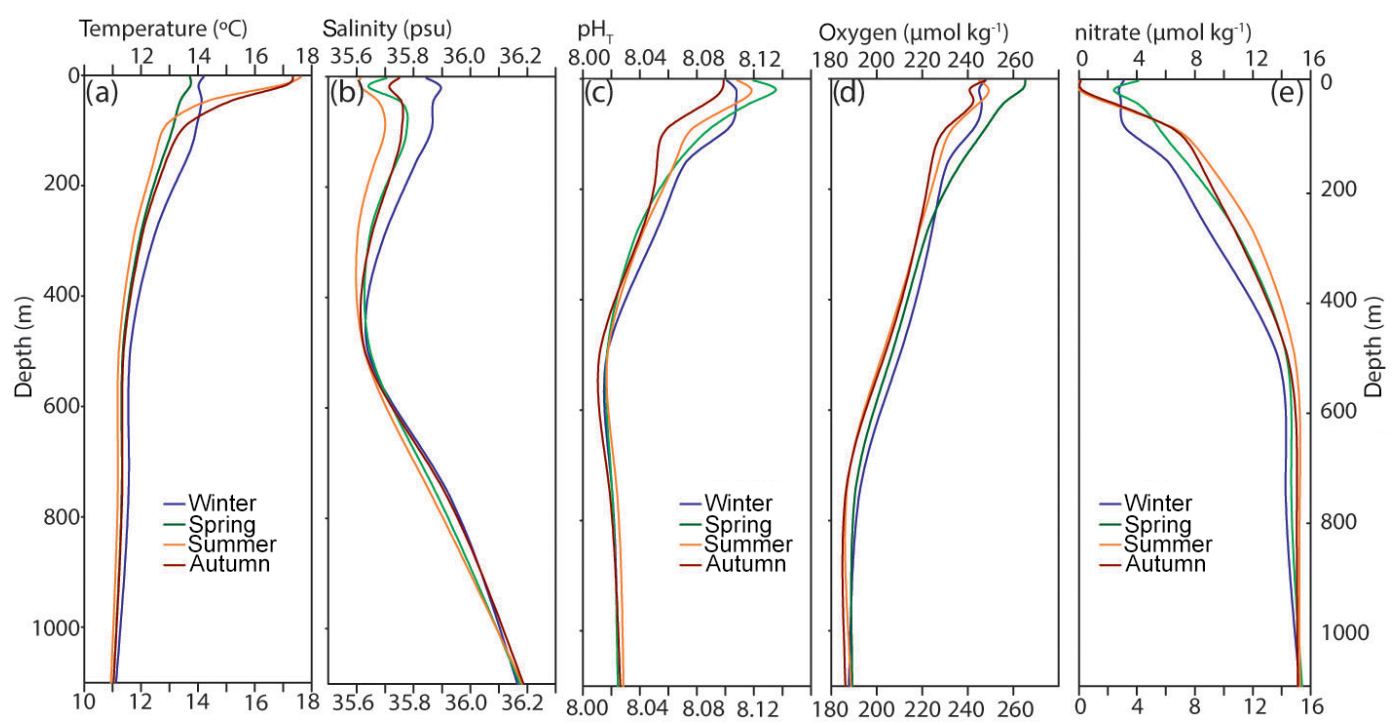

Figure 3. Profiles of seasonal means of temperature (a), salinity (b), $\mathrm{pH}_{T}(\mathbf{c})$, oxygen (d) and nitrate concentration (e) in the first $1100 \mathrm{~m}$ of the region South Ocean shown in Fig. 1.

was estimated for each oceanographic station as the mean value of the depth ranges described in Fig. 2b. These measurements were gathered during the collection periods (December-February, March-May, June-August and September-November) and averaged to describe winter, spring, summer and autumn respectively (Fig. 3, Table A1 in the Appendix).

The vertical distribution of the temperature (Fig. 3a) showed the presence of warmer saline waters throughout the water column in winter with the exception of the surface waters during summer, which showed intense heating due to the radiant solar energy. Below the maximum temperature observed during the summer, cold central waters of subpolar origin occupied the water columns with lower salinity (Fig. 3b). The vertical variation of temperature is typical for a temperate region with relatively homogenous deep water below the seasonal thermocline, reaching maximum sea surface temperature (SST) values in summer and autumn and minimums in spring and winter. The winter temperature profile is relatively warmer than in spring because of the presence of the IPC (Alvarez-Salgado et al., 2006), which reaches a depth of $300 \mathrm{~m}$. The maximum salinity is also found in winter due to the presence of the IPC, whereas the minimum values are found in autumn (Fig. 3b). Below $500 \mathrm{~m}$ in depth, the increase in salinity points to the presence of Mediterranean water. These differences reach a minimum at $500 \mathrm{~m}$ depth, where the salinity values coincided. From this depth down to $1100 \mathrm{~m}$, the differences in temperature and salinity throughout the four seasons were minimal, with the mean values converging to $11.03 \pm 0.07^{\circ} \mathrm{C}$ and $36.117 \pm 0.009 \mathrm{psu}$, respectively (Fig. 3a, b).

The vertical profiles of $\mathrm{pH}_{T}, \mathrm{NO}_{3}^{-}$and oxygen concentration (Fig. 3c-e) also showed a variation lower than
$1 \%$ within this depth range, with annual means of $15.2 \pm$ $0.1 \mu \mathrm{mol} \mathrm{kg}^{-1}, 8.025 \pm 0.005$ and $188 \pm 1 \mu \mathrm{mol} \mathrm{kg}{ }^{-1}$ respectively. The $\mathrm{pH}$ values from a maximum subsurface located at around $40 \mathrm{~m}$ depth showed a clear inverse correlation with the depth down to a depth of $500 \mathrm{~m}$ throughout the seasonal cycle, where the annual minimum value of $8.018 \pm 0.005$ was reached. The higher $\mathrm{pH}$ values could be attributed to the biological reduction of $\mathrm{CO}_{2}$ by phytoplankton activity, which brought the $\mathrm{pH}$ to a maximum value of 8.13 to $40 \mathrm{~m}$ during the spring bloom. After the intense photosynthetic activity observed in surface waters during spring and summer, $\mathrm{pH}$ values reached minimum values in the first $200 \mathrm{~m}$ of depth during autumn due to respiration of organic matter. However, it was at a depth of $500 \mathrm{~m}$ that the minimum $\mathrm{pH}$ values were measured in all seasons where the subpolar Eastern North Atlantic Central Water proceeding from the northeastern cyclonic gyre is found (Harvey, 1982; Ríos et al., 1992). The influence of phytoplankton growth on biogeochemistry during spring can be also evidenced by the oxygen concentration pattern (Fig. 3e). In the upper layer above $250 \mathrm{~m}$ depth, spring oxygen levels exceeded those in winter, whereas a decrease in oxygen concentration was found from this depth down to $1000 \mathrm{~m}$, possibly due to enhanced respiration from cascading organic matter. The impact on the growth of the phytoplankton community during the spring was also evident, judging by the oxygen concentration. So, in the upper waters the spring oxygen concentration values exceeded those of the winter values, while oxygen consumption was found from a depth of 300 to $1000 \mathrm{~m}$ due to respiration from organic matter arriving from above. The minimum values for oxygen concentration throughout the water column were found during summer and autumn. The nitrate concentration displayed a particularly vertical distribution, growing with 


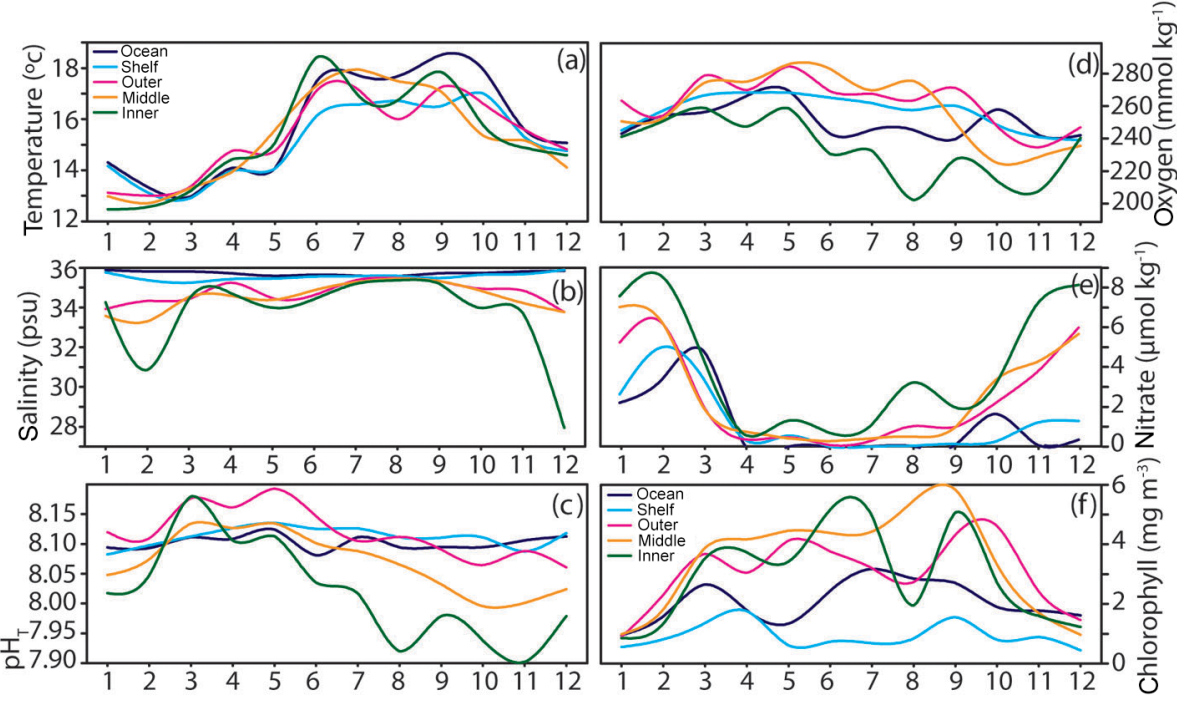

Figure 4. Sea surface ( $<5 \mathrm{~m}$ depth) seasonal cycles in 1976-2018 of temperature (a), salinity $(\mathbf{b}), \mathrm{pH}_{T}(\mathbf{c})$, oxygen concentration $(\mathbf{d})$, nitrate concentration (e) and chlorophyll (f) at sea surface for five geographical boxes shown in Fig. 1: South Ocean, RB shelf, and outer, middle and inner Ría de Vigo for the entire period of the ARIOS database.

depth from minimum values in the upper layer of the ocean region, which was practically zero during the first $50 \mathrm{~m}$. Below $100 \mathrm{~m}$, the nitrate concentration showed the maximum values in the vertical distribution during summer and autumn, coinciding with the presence of waters of subpolar and subtropical origin respectively, whereas the minimum values appeared in winter. Towards the bottom, the seasonal values of $\mathrm{NO}_{3}^{-}$concentration were almost coincident at a mean value of $15.2 \pm 0.1 \mu \mathrm{mol} \mathrm{kg}-1$.

\subsection{Seasonal cycle}

The seasonal cycle of the biogeochemical properties (temperature, salinity, $\mathrm{pH}_{T}$, oxygen concentration, nitrate concentration and chlorophyll) in the surface waters (0 to $5 \mathrm{~m})$ of five geographical boxes was estimated as a monthly average previously filtering values outside of 2 standard deviations of the mean (Table A2 in the Appendix). Five regions that were located as a longitudinal transect between the inner Ría de Vigo and the ocean zone are shown in Fig. 4.

In general terms, the seasonal variability of the temperature was very similar in every area, ranging between 12 and $19^{\circ} \mathrm{C}$ (Fig. 4a). Only particular features observed on a short-term scale as in the examples below differ between each region. The warmer waters were usually found in the oceanic zone, reaching a maximum monthly averaged temperature of $18.6^{\circ} \mathrm{C}$ in September, while the coldest surface waters of $12.6^{\circ} \mathrm{C}$ were located in the inner stations closer to the mouth of the Ría de Vigo in January. Another secondary minimum averaged temperature was also found in the shelf and the outer area of the Ría de Vigo, which was remarkably low in August due to the entry of cold upwelled waters in the surface layer (Alvarez-Salgado, 1993).

The monthly salinity averages (Fig. 4b) clearly showed significant differences between the offshore and coastal waters. Sharp salinity changes were seen in the estuary during winter, especially in the inner area where values lower than 28 psu were reached with the arrival of continental inputs in December. The weak seasonal cycle of salinity in the shelf and ocean waters showed high values in December due to the influence of warm saline water from the IPC, usually located on the shelf slope even though it may even enter the rias depending on the relative intensity of shelf winds and the intensity of the continental runoff (Alvarez-Salgado et al., 2003). In this sense, the slight salinity minimum observed in the shelf waters in March could be consequence of the offshore spreading of the maximum discharges from the River Miño and Douro (Otero et al., 2008) at the end of downwelling season. After this, the shelf and ocean waters showed minimum values in summer due to the arrival of cooler and fresher subpolar waters (Rios et al., 1992; Alvarez-Salgado et al., 2003, 2006). In August, coinciding with the maximum salinity of the surface waters in the interior of the Ría de Vigo due to the minimum river runoff, the surface waters between the inner Ría de Vigo and the ocean region were almost homogeneous, with minimum differences in salinity of $0.2 \mathrm{psu}$.

Like salinity, there was little seasonal variability in $\mathrm{pH}$ in the offshore waters but large seasonal variability in coastal waters, with maximum and minimum $\mathrm{pH}$ values in spring and autumn, respectively, and in all regions (Fig. 4c). The net balance between production and respiration of organic matter and the estuarine circulation caused a maximum $\mathrm{pH}$ 
of 8.19 in the outer region of the Ría de Vigo in May and a minimum of 7.96 in the inner waters in November.

The oxygen concentration (Fig. 4d) in the coastal ecosystems is also controlled by the remineralization of the organic matter and photosynthetic activity of the phytoplankton community, with the effect of salinity and temperature on the oxygen saturation level. The variability in the oxygen concentration, like the $\mathrm{pH}$ distribution, showed a growing seasonal amplitude towards the coastline, with maximum values in the outer and middle Ría de Vigo and lower values in the inner waters, especially during the second half of the seasonal cycle. Hence, the dissolved oxygen concentration mirrored the seasonal cycle of $\mathrm{pH}$, showing growing seasonal amplitude towards the coastline with a range between $284 \mu \mathrm{mol} \mathrm{kg}{ }^{-1}$ found in the outer region of the Ría de Vigo in May and $205 \mu \mathrm{mol} \mathrm{kg}{ }^{-1}$ in the inner waters in November. These results seem to reinforce the importance of the oxygen consumption in this shallow area, where the water column is less than $10 \mathrm{~m}$ deep, and therefore it would also be influenced by benthic respiration (Alonso-Pérez and Castro, 2014).

The monthly means of nitrate concentration (Fig. 4e) could be summarized as high values during autumn and winter due to the nutrients delivered from the continent and the vertical mixing, and as minimum nitrate values from March to September because of phytoplankton consumption. The nitrate concentration was markedly higher in the inner Ría de Vigo, where it exceeded $9 \mu \mathrm{mol} \mathrm{kg}{ }^{-1}$ in February and decreased towards the open ocean, where the highest monthly value was seen to be $2.5 \mu \mathrm{mol} \mathrm{kg}{ }^{-1}$. Some notable aspects can be seen in Fig. 5d, such as water poor in nitrate in the ocean region between the two peaks of $3.5 \mu \mathrm{mol} \mathrm{kg}{ }^{-1}$ in March and $1.3 \mu \mathrm{mol} \mathrm{kg}^{-1}$ in October. This shows the presence of the IPC waters, which are warmer and saltier than the shelf waters. Also noteworthy was the particular fact that while the nitrate concentration in other areas was practically zero in summer, the nitrate amount in the surface waters within the Ría de Vigo, and especially in the inner Ría de Vigo, was not completely consumed. This indicates a constant supply throughout the year, either through upwelling events or the continental inputs. This in turn means that while the chlorophyll values were at a minimum in the offshore waters in summer, the phytoplankton community in the estuary grew in summer during the upwelling relaxation periods (Pérez et al., 2000). The nutrient concentration during spring and summer was only detectable in the newly upwelled waters that can show values up to $6 \mu \mathrm{mol} \mathrm{L}^{-1}$ (Fraga, 1981; Castro et al., 1994). During the cessation of the upwelling season in September and October, the chlorophyll concentration (Fig. 5f) increased again, sustained by nutrients that entered from deeper waters through vertical mixing. It should be noted that there was a coincidence of high chlorophyll in the water column and low oxygen concentration in the inner Ría de Vigo from May to November, indicating the potential importance of benthic fluxes and vertical fluxes (reference).

\subsection{Long-term trends}

The long-term trends of the biogeochemical properties in the surface waters along the described longitudinal transect between the inner Ría de Vigo and the ocean zone were estimated to be the interannual linear rate of the deseasonalized time series, previously removing the monthly means in these regions and assuming a null spatial variability. The significant trends in the ARIOS database, meaning long-term variability, should be interpreted as a combination of the natural variability on a decadal scale (Pérez et al., 2010; Padin et al., 2010) and anthropogenic forcings (Wolf-Gladrow et al., 1999; Anderson and Mackenzie 2012; Bakun et al., 2010).

No long-term temperature variability was found in the surface waters of any region despite the known warming previously reported on the northern Iberian coast (Pérez et al., 2010; Gómez-Gesteira et al., 2011; González-Pola et al., 2005). Unlike the temperature, the other expected consequence of climate change in marine ecosystems, namely ocean acidification (Caldeira and Wickett, 2003), was observed along the longitudinal transect, with a greater decrease in the long-term trend of $\mathrm{pH}$ towards the coast (Table 2). The long-term $\mathrm{pH}$ variation of $-0.0039 \pm 0.0005 \mathrm{yr}^{-1}$ in the inner waters was about 3-fold higher than the change observed in the ocean zone, equivalent to $-0.0012 \pm$ $0.0002 \mathrm{yr}^{-1}$ in the ocean zone, explaining the $34 \%$ and $22 \%$ variation in $\mathrm{pH}$ in situ, respectively, and representing $1 \%-$ $3 \%$ of the seasonal $\mathrm{pH}$ variation in all zones. These $\mathrm{pH}$ decrease rates found in both coastal and open-ocean regions of the Iberian upwelling system lie within the range of other acidification rates estimated in different sites of the North Atlantic Ocean (Lauvset and Gruber, 2014; Bates et al., 2014), being also coherent with the mean rates calculated for the global ocean and for the eastern North Atlantic and equal to -0.018 and -0.0164 decade $^{-1}$, respectively (Lauvset et al., 2015; Ríos et al., 2001).

The long-term trend in salinity was also seen to be evidently dependent on the distance to the mouth of the Ría de Vigo. The interannual rate of sea surface salinity in the outer and inner ria previously reported by Rosón et al. (2009) was $0.0426 \pm 0.016$ and $0.0193 \pm 0.0056 \mathrm{psu} \mathrm{yr}^{-1}$ respectively. These changes were observed in parallel to an interannual alkalinity increase that is cancelled out in the normalized alkalinity, estimated as the difference between the alkalinity measured and the alkalinity calculated using the linear regression with salinity in each region. Therefore, the interannual salinity increase was the forcing that explains the increase in the buffer capacity of the surface waters (Sarmiento and Gruber, 2006).

Other significant long-term variations were found in other biogeochemical parameters in the ARIOS database. The long-term trend of the concentrations of nutrients in the inner Ría de Vigo that had been previously reported for the period 2001-2011 by Doval et al. (2016) showed a significant increase in nitrate, phosphate and ammonium concen- 

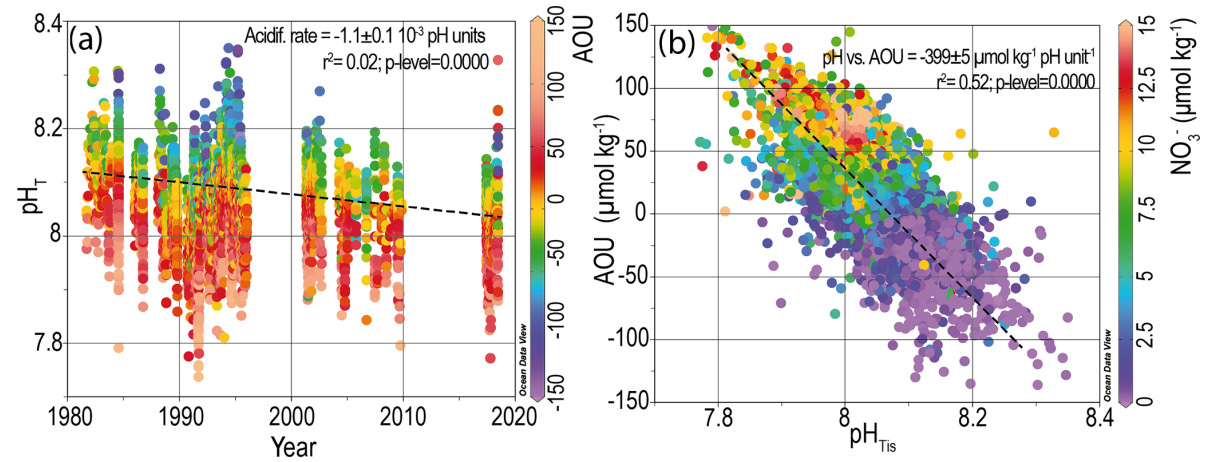

Figure 5. Time series of $\mathrm{pH}$ ARIOS data. The black line depicts the long-term trend. Scatter diagram of $\mathrm{AOU}$ vs. $\mathrm{pH}_{T}$ including the nitrate concentration shown as the colour of every dot.

Table 2. Seasonal amplitude of monthly $\mathrm{pH}$ means (SSrange) and long-term trends ( $t_{\text {interannual }}$ ) of $\mathrm{pH}$ in five regions, and significant regression coefficients between the in situ $\mathrm{pH}$ measurements and the monthly mean $\mathrm{pH}$ values $\left(r^{2} \mathrm{ss}\right)$ and the regression coefficient of the temporal variability of the deseasonalized $\mathrm{pH}$ measurements $\left(r^{2}\right)$.

\begin{tabular}{lccccc}
\hline & SSrange & $r^{2} \mathrm{ss}$ & $t_{\text {interannual }}$ & $r^{2}$ & $p$ value \\
\hline OCEAN & 0.050 & 0.17 & $-0.0012 \pm 0.0002$ & 0.21 & 0.0000 \\
SHELF & 0.050 & 0.06 & $-0.0017 \pm 0.0003$ & 0.15 & 0.0009 \\
OUTER & 0.120 & 0.24 & $-0.0027 \pm 0.0003$ & 0.21 & 0.0000 \\
MIDDLE & 0.130 & 0.28 & $-0.0022 \pm 0.0005$ & 0.03 & 0.0000 \\
INNER & 0.260 & 0.47 & $-0.0039 \pm 0.0005$ & 0.34 & 0.0000 \\
\hline
\end{tabular}

trations of $0.0559 \pm 0.0158,0.0076 \pm 0.0016$ and $0.0560 \pm$ $0.0011 \mu \mathrm{mol} \mathrm{kg}{ }^{-1} \mathrm{yr}^{-1}$ respectively. This fertilization on a long-term scale in the surface waters of the inner ria estimated from the ARIOS database was observed in parallel to the deoxygenation of $-0.7 \pm 0.2 \mu \mathrm{mol} \mathrm{kg} \mathrm{yr}^{-1}$. The apparent oxygen utilization (AOU), calculated using the concentration of $\mathrm{O}_{2}$ at saturation calculated according to Benson and Krause (1984), underwent an equivalent significant longterm change of $0.7 \pm 0.2 \mu \mathrm{mol} \mathrm{kg}{ }^{-1} \mathrm{yr}^{-1}$, indicating that either the biological consumption rates, a change in the amount of time that the waters are ventilated, or even its interaction or exchange with the sediment cause the long-term reduction of oxygen.

This fertilization on a long-term scale estimated from the ARIOS database in the surface waters of the inner ria was observed in parallel to the deoxygenation of $-0.7 \pm$ $0.2 \mu \mathrm{mol} \mathrm{kg} \mathrm{kg}^{-1}$. The apparent oxygen utilization (AOU), calculated using the concentration of oxygen at saturation calculated according to Benson and Krause (1984), underwent a long-term change of $0.7 \pm 0.2 \mu \mathrm{mol} \mathrm{kg}^{-1} \mathrm{yr}^{-1}$ equal to that observed in the measurements of oxygen concentration. This coincidence may indicate that the long-term reduction of oxygen is due to the changes in the biological consumption rates, in the rates of the waters ventilation or even in sediment-water interactions rather than due to the effect of temperature and salinity on oxygen saturation.
These findings found in the shallower waters of the Ría de Vigo allow us to hypothesize that the long-term increase in salinity would produce an increasingly weak vertical salinity gradient in the water column that would favour the vertical fluxes between the bottom and surface waters. Therefore the observed changes of oxygen and remineralized nutrient inputs in the surface waters could be due to an increasing footprint of benthic respiration, which has a major importance in the net ecosystem metabolism of this coastal region (AlonsoPérez et al., 2015). This hypothesis would also explain the intense acidification in the inner waters in spite of growing alkalinity buffering.

The mean values at each station of the ARIOS database estimated for each depth range described in Fig. 2, resulting in 8384 values, were used to estimate a general value of the long-term trend in $\mathrm{pH}$. The historical $\mathrm{pH}$ values in situ from the ARIOS database showed a general decrease in seawater $\mathrm{pH}$ in the Iberian upwelling between 1976 and 2018, with an acidification rate of $-0.012 \pm 0.002 \mathrm{yr}^{-1}$ that significantly explains $2 \%$ of the total $\mathrm{pH}$ variation (Fig. 5a). The apparent oxygen utilization was also shown as function of $\mathrm{pH}$ over time, revealing the association of higher $\mathrm{AOU}$ values with lower $\mathrm{pH}$. The relationship between $\mathrm{pH}$ and AOU (Fig. $5 \mathrm{~b}$ ) showed an inverse linear correlation of $-399 \pm 5 \mu \mathrm{mol} \mathrm{kg}{ }^{-1}$ and a coefficient of determination $\left(r^{2}\right)$ of 0.52 . The strong biological activity of the upwelling systems is the main driver of $\mathrm{pH}$ changes, explaining $52 \%$ of the observed variation in 
the discrete measurements. The distribution of nitrate seen in relation to the distribution of $\mathrm{pH}$ and $\mathrm{AOU}$ (Fig. 5b) showed the association of higher $\mathrm{pH}$ values with negative AOU values and a nitrate decrease, reinforcing the importance of biological processes in these marine carbonate system. Although the different processes controlling the AOU values were not separated in this analysis, the oxygen concentration in addition to the remineralization of the organic matter and the photosynthesis is conditioned by changes in temperature and salinity, ventilation events, water masses mixing and other processes (Sarmiento and Gruber, 2006). Therefore, the long-term drop in seawater $\mathrm{pH}$ measurements estimated from the ARIOS database presented here confirms that the future evolution of ocean acidification in this productive region is likely to depend on both the $\mathrm{CO}_{2}$ increase in the atmosphere and other long-term changes (of natural and/or anthropogenic origin) affecting the seawater's carbonate system.

\section{Data availability}

The ARIOS dataset (Pérez et al., 2020) is archived at Digital CSIC under the digital object identifier (DOI) https://doi.org/10.20350/digitalCSIC/12498.

The data are available as WHP-Exchange bottle format (arios_database_hyl.csv). A documentation file (readme_ARIOSDATABASE.txt) provides a description of the materials and methods of the measurements and the parameters of the dataset. In both files, a table similar to the Table 1 of this paper includes the DOI and the EXPOCODE of the original cruise files gathered in the ARIOS dataset.

These data are available to the public and the scientific community with the hope that their wide dissemination will lead to new scientific knowledge about the ocean acidification and the biogeochemistry of the Galicia upwelling system. The dataset is subject to a Creative Commons License Attribution-ShareAlike 4.0 International and users of the ARIOS dataset should reference this work.

\section{Conclusions}

The ARIOS database is a unique compilation of biogeochemical discrete measurements in the Iberian upwelling ecosystem from 1976 to 2018. This dataset comprises more than 17653 discrete samples from 3357 oceanographic stations (but not always for all parameters) of $\mathrm{pH}$, alkalinity, and associated physical and biogeochemical parameters (e.g. temperature, salinity, and chlorophyll and oxygen concentrations). The materials and methods varied throughout the sampling period due to logistical and analytical issues such as those described in Table 1, where different sites are mentioned to download these measurements and detailed information.

Among the results described as preliminary and relevant information to learn the environmental and oceanographic context of the ARIOS database, we can mention the following main points concerning the $\mathrm{pH}$ characteristics of the Iberian upwelling system:

- A decrease in seawater $\mathrm{pH}$ in the Iberian upwelling between 1976 and 2018, with an acidification rate of $-0.012 \pm 0.002 \mathrm{yr}^{-1}$ that significantly explains $2 \%$ of the total $\mathrm{pH}$ variation.

- An interannual $\mathrm{pH}$ variation of $-0.0039 \pm 0.0005 \mathrm{yr}^{-1}$ in the inner waters and $-0.0012 \pm 0.0002 \mathrm{yr}^{-1}$ in the ocean zone.

- An inverse linear correlation between $\mathrm{pH}$ and AOU of $-399 \pm 5 \mu \mathrm{mol} \mathrm{kg}{ }^{-1}$ that explained $52 \%$ of the observed variation in the discrete measurements.

This published ARIOS database is a useful and necessary tool to confirm and study the long-term trend of biogeochemical changes in seawater. Likewise, we understand that it is a starting point to which to add future observation projects to continue increasing the knowledge about the impact of climate change in the Iberian upwelling ecosystem.

Supplement. The supplement related to this article is available online at: https://doi.org/10.5194/essd-12-2647-2020-supplement.

Author contributions. XAP, AV and FFP designed the study. The manuscript was written by XAP and revised and discussed by all the authors. The ARIOS database was created by FFP and AV.

Competing interests. The authors declare that they have no conflict of interest.

Acknowledgements. We thank all of the scientists, technicians, personnel, and crew who were responsible for the collection and analysis of the over 22000 samples included in the final dataset. In addition to the PI cited in Table 1 we also thank Trinidad Rellán, Antón Velo, Miguel Gil Coto, Marta Alvarez, Marylo Doval, Jesus Gago, Daniel Broullón and Marcos Fontela. We also thank Monica Castaño for starting this data compilation more than 10 years ago.

Financial support. The compilation of this dataset was funded by the ARIOS project (CTM2016-76146-C3-1-R) funded by the Spanish government through the Ministerio de Economía y Competitividad that included European FEDER funds. Part of the processing work was supported by the MarRISK project (European Union FEDER 0262_MarRISK_1_E) funded by the Programme 2014-2020 Interreg V-A-Spain-Portugal (POPTEC). This project has also received funding from the European Union's Horizon 2020 research and innovation programme under grant agreement no. 820989 (project COMFORT, Our common future ocean in the Earth system - quantifying coupled cycles of carbon, oxygen, and 
nutrients for determining and achieving safe operating spaces with respect to tipping points).

Review statement. This paper was edited by Giuseppe M. R. Manzella and reviewed by Michele Giani and one anonymous referee.

\section{References}

Alonso-Perez, F. and Castro, C. G.: Benthic oxygen and nutrient fluxes in a coastal upwelling system (Ria de Vigo, NW Iberian Peninsula): seasonal trends and regulating factors, Mar. Ecol. Prog. Ser., 511, 17-32, https://doi.org/10.3354/meps10915, 2014.

Alonso-Perez F., Ysebaert, T., and Castro, C. G.: Effects of suspended mussel culture on benthic-pelagic coupling in a coastal upwelling system (Ría de Vigo, NW Iberian Peninsula), J. Exp. Mar. Biol. Ecol., 382, 96-107, https://doi.org/10.1016/j.jembe.2009.11.008, 2010.

Alonso-Perez, F., Zúñiga, D., Arbones, B., Figueiras, F. G., and Castro, C. G.: Benthic fluxes, net ecosystem metabolism and seafood harvest: Completing the organic carbon balance in the Ría de Vigo (NW Spain), Estuar. Coast. Shelf Sci., 163, 54-63, https://doi.org/10.1016/j.ecss.2015.05.038, 2015.

Alvarez, M., Fernández, E., and Pérez, F. F.: Air-sea $\mathrm{CO}_{2}$ fluxes in a coastal embayment affected by upwelling: physical versus biological control, Oceanol. Acta, 22, 499-515, 1999.

Alvarez-Salgado, X. A., Rosón, G., Pérez, F. F., and Pazos, Y.: Hydrographic variability off the Rías Baixas (NW Spain) during the upwelling season, J. Geophys. Res., 98, 14447-14455, 1993.

Alvarez-Salgado, X. A., Figueiras, F. G., Villarino, M. L., and Pazos, Y.: Hydrodynamic and chemical conditions during onset of a red-tide assemblage in an estuarine upwelling ecosystem, Mar. Biol., 130, 509-519, 1998.

Álvarez-Salgado, X. A., Doval, M. D., Borges, A. V, Joint, I., Frankignoulle, M., Woodward, E. M. S., and Figueiras, F. G.: Off-shelf fluxes of labile materials by an upwelling filament in the NW Iberian Upwelling System, Prog. Oceanogr., 51, 321337, 2001 .

Álvarez-Salgado, X. A., Beloso, X., Joint, I., Nogueira, E., Chou, L., Pérez, F. F., Groom, S., Cabanas, J. M., Rees, A. P., and Elskens, M.: New Production of the NW Iberian Shelf during the Upwelling Season over the period 1982-1999, Deep-Sea Res., 49, 1725-1739, https://doi.org/10.1016/S0967-0637(02)000948, 2002.

Álvarez-Salgado, X. A., Figueiras, F. G., Pérez, F. F., Groom, S., Nogueira, E., Borges, A. V., Chou, L., Castro, C. G., Moncoiffé, G., Ríos, A. F., Miller, A. E. J., Frankignoulle, M., Savidge, G., and Wollast, R.: The Portugal coastal counter current off NW Spain new insights on its biogeochemical variability, Prog. Oceanogr., 56, 281-321, https://doi.org/10.1016/S00796611(03)00007-7, 2003.

Álvarez-Salgado, X. A., Nieto-Cid, M., Piedracoba, S., Crespo, B. G., Gago, J., Brea, S., Teixeira, I. G., Figueiras, F. G., Garrido, J. L., Rosón, G., Castro, C. G., and Gilcoto, M.: Origin and fate of a bloom of Skeletonema costatum during a winter upwelling/downwelling sequence in the
Ría de Vigo (NW Spain), J. Mar. Res., 63, 1127-1149, https://doi.org/10.1357/002224005775247616, 2005.

Alvarez-Salgado, X. A., Nieto-Cid, M., Gago, J., Brea, S., Castro, C. G., Doval, M., and Pérez, F. F.: Stoichiometry of the degradation of dissolved and particulate biogenic organic matter in the NW Iberian upwelling, J. Geophys. Res., 111, C07017, https://doi.org/10.1029/2004JC002473, 2006.

Alvarez-Salgado, X. A., Labarta, U., Fernández-Reiriz, M. J., Figueiras, F. G., Rosón, G., Piedracoba, S., Filgueira, R., and Cabanas, J. M.: Renewal time and the impact of harmful algal blooms on the extensive mussel raft culture of the Iberian coastal upwelling system (SW Europe), Harmful Algae, 7, 849855, https://doi.org/10.1016/j.hal.2008.04.007, 2008

Anderson, L.: Correction of reversing thermometers andrelated depth calculations in Baltic water, Meddelande fran Havsfiskelaboratoriet, Lysekil, 166 pp., 1974.

Andersson, A. J. and Mackenzie, F. T.: Revisiting four scientific debates in ocean acidification research, Biogeosciences, 9, 893905, https://doi.org/10.5194/bg-9-893-2012, 2012.

Arístegui J., Barton, E. D., Tett, P., Montero, M. F., GarcíaMuñoz, M., Basterretxea, G., Cussatlegras, A. S., Ojeda, A., and de Armas, D.: Variability in plankton community structure, metabolism, and vertical carbon fluxes along an upwelling filament (Cape Juby, NW Africa), Prog. Oceanogr., 62, 95-113, 2004.

Bakun, A., Field, D. B., Redondo-Rodriguez, A., and Weeks, S. J.: Greenhouse gas, upwelling favorable winds, and the future of coastal ocean upwelling ecosystems, Glob. Change Biol., 16, 4, 1213-1228, https://doi.org/10.1111/j.1365-2486.2009.02094.x, 2010.

Barnes, H.: Apparatus and methods of oceanography. Part one: Chemical, Allen and Unwin. London, 335 pp., 1959.

Barton, E. D., Largier, J. L., Torres, R., Sheridan, M., Trasviña, A., Souza A., Pazos, Y., and Valle-Levinson, A.: Coastal upwelling and downwelling forcing of circulation in a semienclosed bay: Ria de Vigo, Prog. Oceanogr., 134, 173-189, https://doi.org/10.1016/j.pocean.2015.01.014, 2015.

Barton, E. D., Torres, R., Figueiras, F. G., Gilcoto, M., and Largier, J.: Surface water subduction during a downwelling event in a semienclosed bay, J. Geophys. Res., 121, 7088-7107, https://doi.org/10.1002/2016JC011950, 2016.

Barton, E. D., Castro, C. G., Alonso-Pérez, F., Zúñiga, D., Rellán, T., Arbones, B., Castaño, M., Gilcoto, M., Torres, R., Figueiras, F. G., Pérez, F. F., and Ríos, A. F.: Cria surveys: hydrographic and chemical data, Digital.CSIC, https://doi.org/10.20350/digitalCSIC/9931, 2019.

Bates, N. R., Astor, Y. M., Church, M. J., Currie, K., Dore, J. E., González-Dávila, M., Lorenzoni, L., Muller-Karger, F., Olafsson, J., and Santana-Casiano, J. M.: A Time-Series View of Changing Surface Ocean Chemistry Due to Ocean Uptake of Anthropogenic $\mathrm{CO}_{2}$ and Ocean Acidification, Oceanography, 27, 126-141, 2014.

Benson, B. B. and Krause, D. J.: The concentration and isotopic fractionation of oxygen dissolved in fresh water and seawater in equilibrium with the atmosphere, Limnol. Oceanogr., 29, 620632,1984

Blanton, J. O., Atkinson, L. P., Fernandez de Castillejo, F., and Lavin Montero, A.: Coastal upwelling off the Rias Bajas, Galicia, Northwest Spain, I: Hydrography studies, Rapports et procès- 
verbaux des réunions: The biological productivity of North Atlantic Shelf areas, 183, 79-90, 1984.

Bode, A., Alvarez-Ossorio, M. T., Cabanas, J. M., Miranda, A., and Varela, M.: Recent trends in plankton and upwelling intensity off Galicia (NW Spain), Prog. Oceanogr., 83, 342-350, 2009.

Caldeira, K. and Wickett, M. E.: Oceanography: anthropogenic carbon and ocean $\mathrm{pH}$, Nature, 425, 365, https://doi.org/10.1038/425365a, 2003.

Castro, C. G., Pérez, F. F., Álvarez-Salgado, X. A., Rosón, G., and and Ríos, A. F.: Hydrographic conditions associated with the relaxation of an upwelling event off the Galician coast (NW Spain), J. Geophys. Res., 99, 5135-5147, https://doi.org/10.1029/93JC02735, 1994.

Castro, C. G., Nieto-Cid, M., Álvarez-Salgado, X. A., and Pérez, F. F.: Local remineralization patterns in the mesopelagic zone of the ENAW, Deep-Sea Res. Pt I, 53, 1925-1940, https://doi.org/10.1016/j.dsr.2006.09.002, 2006.

Castro, C. G., Álvarez-Salgado, X. A., Nogueira, E., Gago, J., Pérez, F. F., Bode, A., Ríos, A. F., Rosón, G., and Varela, M.: Evidencias bioxeoquímicas do cambio climático. Edita: Xunta de Galicia. Consellería de Medio Ambiente e Desenvolvemento Sostible, Evidencias e impactos do cambio climático en Galicia, 303-326, 2009.

Clayton, T. D. and Byrne, R. H.: Spectrophotometric seawater $\mathrm{pH}$ measurements: total hydrogen ion concentration scale calibration of m-cresol purple and at-sea results, Deep-Sea Res. Pt. I, 40, 2115-2129, https://doi.org/10.1016/0967-0637(93)90048-8, 1993.

Cobo-Viveros, A. M., Padin, X. A., Otero, P., de la Paz, M., RuizVillareal, M., Ríos, A. F., and Pérez, F. F.: Short-term variability of surface carbon dioxide and sea-air $\mathrm{CO}_{2}$ fluxes in the shelf waters of the Galician coastal upwelling system, Scientia Marina, 77S1, 37-48, https://doi.org/10.3989/scimar.03733.27C, 2013.

Culberson, C. H., Knapp, G., Stalcup, M. C., Williams, R. T., and Zemlyak, F.: A comparison of methods for the determination of dissolved oxygen in seawater, WOCE Report 73/91, 77 pp., 1991.

DelValls, T. A. and Dickson, A. G.: The pH of buffers based on 2amino-2-hydroxymethyl-1,3-propanediol ("tris") in synthetic sea water, Deep-Sea Res. Pt. I, 45, 1541-1554, 1998.

Dickson, A. G., Sabine, C. L., and Christian, J. R.: Guide to best practices for ocean $\mathrm{CO}_{2}$ measurements, PICES Special Publication 3, 191 pp., 2007.

Doval, M., Nogueira, E., and Pérez, F. F.: Spatio-temporal variability of the thermohaline and biogeochemical properties and dissolved organic carbon in a coastal embayment affected by upwelling: the Ría de Vigo (NW Spain), J. Mar. Syst., 14, 135-150, https://doi.org/10.1016/S0924-7963(97)80256-4, 1998.

Doval, M. D., Alvarez-Salgado, X. A., and Perez, F. F.: Dissolved organic carbon in a temperate embayment affected by coastal upwelling, Mar. Ecol. Prog. Ser., 157, 21-37, https://doi.org/10.3354/meps157021, 1997a.

Doval, M. D., Fraga, F., and Perez, F. F.: Determination of dissolved organic nitrogen in seawater using Kjeldahl digestion after inorganic nitrogen removal, Oceanol. Acta, 20, 713-720, 1997b.

Doval, M. D., López, A., and Madriñán, M.: Temporal variation and trends of inorganic nutrients in the coastal upwelling of the NW Spain (Atlantic Galician rías), J. Sea Res., 108, 19-29, https://doi.org/10.1016/j.seares.2015.12.006, 2016.
Feely, R. A., Sabine, C. L., Hernandez-Ayon, J. M., Ianson, D., and Hales, B: Evidence for upwelling of corrosive "acidified" water onto the continental shelf, Science, 320, 1490-1492, https://doi.org/10.1126/science.1155676, 2008.

Figueiras, F. G., Jones, K., Mosquera, A. M., Álvarez Salgado, X. A., Edwards, A., and MacDougall, N.: Red tide assemblage formation in an estuarine upwelling ecosystem: Ria de Vigo, J. Plankt. Res., 16 857-878, https://doi.org/10.1093/plankt/16.7.857, 1994.

Fraga F.: Upwelling off the Galician coast, northwest Spain, Coastal Upwelling, American Geophysical Union, Washington DC, 176182, https://doi.org/10.1029/CO001p0176, 1981.

Fraga, F., Mouriño, C., and Manriquez, M.: Las masas de agua en la costa de Galicia: junio-octubre, Resultados Expediciones Científicas, 10, 51-77, http://hdl.handle.net/10261/90380, 1982.

Fraga, F., Pérez, F. F., Figueiras, F. G., and Ríos, A. F.: Stoichiometric variations of $\mathrm{N}, \mathrm{P}, \mathrm{C}$ and $\mathrm{O}_{2}$ during a Gymnodinium catenatum red tie and their interpretation, Marine Ecology Progress Series, 87, 123-134, https://doi.org/10.3354/meps087123, 1992.

Froján, M., Arbones, B., Zúñiga, D., Castro, C. G., and Figueiras, F. G.: Microbial plankton community in the Ría de Vigo (NW Iberian upwelling system): impact of the culture of Mytilus galloprovincialis, Mar. Ecol. Prog. Ser., 498, 43-54, https://doi.org/10.3354/meps10612, 2014.

Froján, M., Figueiras, F. G., Zúñiga, D., Alonso-Pérez, F., Arbones, B., and Castro, C. G.: Influence of Mussel Culture on the Vertical Export of Phytoplankton Carbon in a Coastal Upwelling Embayment (Ría de Vigo, NW Iberia), Estuar. Coast., 39, 1449-1462, https://doi.org/10.1007/s12237-016-0093-1, 2016.

Froján, M., Castro, C. G., Zúñiga, D., Arbones, A., Alonso-Pérez, F., and Figueiras, F. G.: Mussel farming impact on pelagic production and respiration rates in a coastal upwelling embayment (Ría de Vigo, NW Spain), Estuar. Coast. Shelf Sci., 204, 130 139, https://doi.org/10.1016/j.ecss.2018.02.025, 2018.

Frouin, R., Fiúza, A. F. G., Ambar, I., and Boyd, T. J.: Observations of a poleward surface current off the coasts of Portugal and Spain during winter, J. Geophys. Res., 95, 679-691, 1990.

Gago, J., Alvarez-Salgado, X. A., Gilcoto, M., and Pérez, F. F.: Assessing the contrasting fate of dissolved and suspended organic carbon in a coastal upwelling system (Ría de Vigo, NW Iberian Peninsula), Estuar. Coast. Shelf Sci., 56, 271-279, https://doi.org/10.1016/S0272-7714(02)00186-5, 2003a.

Gago, J., Alvarez-Salgado, X. A., Pérez, F. F., and Ríos, A. F.: Partitioning of physical and biogeochemical contributions to short-term variability of $p \mathrm{CO}_{2}$ in a coastal upwelling system a quantitative approach, Mar. Ecol. Progr., 255, 43-54, https://doi.org/10.3354/meps25504, 2003b.

Gago, J., Gilcoto, M., Pérez, F. F., and Ríos, A.F.: Short-term variability of $\mathrm{fCO}_{2}$ in seawater and air-sea $\mathrm{CO}_{2}$ fluxes, Mar. Chem., 80, 247-264, https://doi.org/10.1016/S0304-4203(02)00117-2, $2003 \mathrm{c}$.

Gilcoto, M., Largier, J. L., Barton, E. D., Piedracoba, S., Torres, R., Graña, R., Alonso-Pérez, F., Villacieros-Robineau, N., and de la Granda, F.: Rapid response to coastal upwelling in a semienclosed bay, Geophys. Res. Lett., 44, 2388-2397, https://doi.org/10.1002/2016GL072416, 2017.

Gómez-Gesteira, M., Gimeno, L., deCastro, M., Lorenzo, M. N., Alvarez, I., Nieto, R., Taboada, J. J., Crespo, A. J. C., Ramos, A. M., Iglesias, I., Gómez-Gesteira, J. L., Santo, F. E., Barriopedro, 
D., and Trigo, I. F.: The state of climate in NW Iberia, Clim. Res., 48, 109-144, https://doi.org/10.3354/cr00967, 2011.

González-Pola, C., Lavín, A., and Vargas-Yáñez, M.: Intense warming and salinity modification of intermediate water masses in the southeastern corner of the Bay of Biscay for the period 1992-2003, J. Geophys. Res., 110, C05020, https://doi.org/10.1029/2004JC002367, 2005.

Grasshoff, K. and Johannsen, H.: A New Sensitive and Direct Method for the Automatic Determination of Ammonia in Sea Water, ICES J. Mar. Sci., 34, 516-521, https://doi.org/10.1093/icesjms/34.3.516, 1972.

Grasshoff, K., Ehrhardt, M., and Kremlin, K.: Methods of Seawater Analysis, 2nd. edn., Wiley-VCH Verlag, Weinheim, 419 pp., 1983.

Gruber, N., Hauri, C., Lachkar, Z., Loher, D., Frolicher, T. L., and Plattner, G. K.: Rapid progression of ocean acidification in the California Current System, Science, 337, 220-223, https://doi.org/10.1126/science.1216773, 2012.

Harvey, J.: $\theta$-S relationship and water masses in the eastern North Atlantic, Deep-Sea Res., 29, 1021-1033, 1982.

Hauri, C., Gruber, N., Plattner, G. K., Alin, S., Feely, R. A., Hales, B., and Wheeler, P. A.: Ocean acidification in the California Current System, Oceanography, 22, 58-69, https://doi.org/10.5670/oceanog.2009.97, 2009.

Hauri, C., Gruber, N., Vogt, M., Doney, S. C., Feely, R. A., Lachkar, Z., Leinweber, A., McDonnell, A. M. P., Munnich, M., and Plattner, G.-K.: Spatiotemporal variability and long-term trends of ocean acidification in the California Current System, Biogeosciences, 10, 193-216, https://doi.org/10.5194/bg-10-193-2013, 2013.

Hofmann, G. E.: High-frequency dynamics of ocean pH: A multi-ecosystem comparison, PLoS One, 6, e28983, https://doi.org/10.1371/journal.pone.0028983, 2011.

IPCC: Climate Change 2013: the physical science basis Contribution of Working Group I to the Fifth Assessment Report of the Intergovernmental Panel on Climate Change, edited by: Stocker, T. F., Qin, D., Plattner, G.-K., Tignor, M., Allen, S. K., Boschung, J., Nauels, A., Xia, Y., Bex, V., and Midgley, P. M., Cambridge: Cambridge University Press, 1535 pp., 2013.

Lachkar, Z.: Effects of upwelling increase on ocean acidification in the California and Canary Current systems, Geophys. Res. Lett., 41, 90-95, https://doi.org/10.1002/2013GL058726, 2014.

Lassoued. J., Babarro, J., Padín, X. A., Comeau, L., Bejaoui, N., and Pérez, F.: Behavioural and eco-physiological responses of the mussel Mytilus galloprovincialis to acidification and distinct feeding regimes, Mar. Ecol. Prog. Ser., 626, 97-108, https://doi.org/10.3354/meps13075, 2019.

Lauvset, S. K. and Gruber, N.: Long-term trends in surface ocean $\mathrm{pH}$ in the North Atlantic, Mar. Chem., 162, 71-76, https://doi.org/10.1016/j.marchem.2014.03.009, 2014.

Lauvset, S. K., Gruber, N., Landschützer, P., Olsen, A., and Tjiputra, J.: Trends and drivers in global surface ocean $\mathrm{pH}$ over the past 3 decades, Biogeosciences, 12, 1285-1298, https://doi.org/10.5194/bg-12-1285-2015, 2015.

Lemos, R. T. and Sansó, B.: Spatio-temporal variability of ocean temperature in the Portugal Current System, J. Geophys. Res., 111, C04010, https://doi.org/10.1029/2005JC003051, 2006.

Lewis, E. and Wallace, D. W. R.: Program developed for $\mathrm{CO}_{2}$ system calculations, ORNL/CDIAC-105, Carbon Dioxide Infor- mation Analysis Center, Oak Ridge National Laboratory, Oak Ridge, TN, USA, 1998.

Lueker, T. J., Dickson, A. G., and Keeling, C. D.: Ocean $p \mathrm{CO}_{2}$ calculated from dissolved inorganic carbon, alkalinity, and equations for K-1 and K-2: validation based on laboratory measurements of $\mathrm{CO}_{2}$ in gas and seawater at equilibrium, Mar. Chem., 70, 105-119, 2000.

McElhany, P. and Shallin Busch, D.: Appropriate $p \mathrm{CO}_{2}$ treatments in ocean acidification experiments, Mar. Biol., 160, 1807-1812, https://doi.org/10.1007/s00227-012-2052-0, 2013.

Mehrbach, C., Culberson, C. H., Hawley, J. E., and Pytlowicz, R. M.: Measurements of the apparent dissociation constant of carbonic acid in seawater at atmospheric pressure, Limnol. Oceanogr., 18, 897-907, 1973.

Miguez, B. M., Fariña-Busto, L., Figueiras, F. G., and Pérez, F. F.: Succession of phytoplankton assemblages in relation to estuarine hdrodynamics in the Ria de Vigo, Scientia Marina, 65, 65-76, https://doi.org/10.3989/scimar.2001.65s165, 2001.

Mouriño, C. and Fraga, F.: Determinación de nitratos en agua de mar, Investigaciones Marinas, 49, 81-96, 1985.

Nieto-Cid, M., Alvarez-Salgado, X. A., Brea, S., and Pérez, F. F.: Cycling of dissolved and particulate carbohydrates in a coastal upwelling system (NW Iberian Peninsula), Mar. Ecol. Prog. Ser., 283, 39-54, https://doi.org/10.3354/meps283039, 2004.

Nieto-Cid, M., Alvarez-Salgado, X. A., and Pérez, F. F.: Microbial and photochemical reactivity of fluorescent dissolved organic matter in a coastal upwelling system, Limnol. Oceanogr., 51, 1391-1400, https://doi.org/10.4319/lo.2006.51.3.1391, 2006.

Nogueira, E., Pérez, F. F., and Ríos, A. F.: Seasonal and long-term trends in an estuarine upwelling ecosystem (Ría de Vigo, NW Spain), Estuarine, Coast. Shelf Sci., 44, 285-300, 1997.

Olsen, A., Lange, N., Key, R. M., Tanhua, T., Álvarez, M., Becker, S., Bittig, H. C., Carter, B. R., Cotrim da Cunha, L., Feely, R. A., van Heuven, S., Hoppema, M., Ishii, M., Jeansson, E., Jones, S. D., Jutterström, S., Karlsen, M. K., Kozyr, A., Lauvset, S. K., Lo Monaco, C., Murata, A., Pérez, F. F., Pfeil, B., Schirnick, C., Steinfeldt, R., Suzuki, T., Telszewski, M., Tilbrook, B., Velo, A., and Wanninkhof, R.: GLODAPv2.2019an update of GLODAPv2, Earth Syst. Sci. Data, 11, 1437-1461, https://doi.org/10.5194/essd-11-1437-2019, 2019.

Orr, F. M.: Onshore Geologic Storage of $\mathrm{CO}_{2}$, Science, 25, 1656 1658, https://doi.org/10.1126/science.1175677, 2009.

Otero, P., Ruiz-Villarreal, M., and Peliz, A.: Variability of river plumes off Northwest Iberia in response to wind events, J. Mar Syst., 72, 238-255, 2008.

Padin X. A., Castro, C. G., Ríos, A. F., and Pérez, F. F.:Oceanic $\mathrm{CO}_{2}$ uptake and biogeochemical variability during the formation of the Eastern North Atlantic Central water under two contrasting NAO scenarios, J. Mar. Syst., 84, 96-105, https://doi.org/10.1016/j.jmarsys.2010.10.002, 2010.

Pauly, D. and Christensen, V.: Primary production required to sustain global fisheries, Nature, 374, 255-257, 1995.

Pérez, F. F. and Fraga, F.: A precise and rapid analytical procedure for alkalinity determination, Mar. Chem., 21, 169-182, 1987a.

Pérez, F. F. and Fraga, F.: The $\mathrm{pH}$ measurements in seawater on the NBS scale, Mar. Chem., 21, 315-327, 1987b.

Pérez, F. F., Rios, A. F., and Rosón, G.: Sea surface carbon dioxide off the Iberian Peninsula North Eastern Atlantic Ocean, J. Mar. Syst., 19, 27-46, 1999. 
Perez, F. F., Alvarez-Salgado, X. A., and Rosón, G.: Stoichiometry of the net ecosystem metabolism in a coastal inlet affected by upwelling, The Ria de H (NW Spain), Mar. Chem., 69, 217-236, 2000.

Pérez, F. F., Padin, X. A., Pazos, Y., Gilcoto, M., Cabanas, M., Pardo, P. C., Doval, M., D., and Farina-Busto, L.: Plankton response to weakening of the Iberian coastal upwelling, Glob. Change Biol., 16, 1258-1267, 2010.

Pérez, F. F., Velo, A., Padin, X. A., Doval, M. D., and Prego, R.: ARIOS DATABASE: An Acidification Ocean Database for the Galician Upwelling Ecosystem, Instituto de Investigaciones Marinas, Consejo Superior de Investigaciones Cientificas (CSIC), https://doi.org/10.20350/digitalCSIC/12498, 2020.

Piedracoba, S., Alvarez-Salgado, X. A., Rosón G., and Herrera, J. L.: Short timescale thermohaline variability and residual circulation in the central segment of the coastal upwelling system of the Ría de Vigo (northwest Spain) during four contrasting periods, J. Geophys. Res., 110, C03018, https://doi.org/10.1029/2004JC002556, 2005.

Prego, R., Fraga, F., and Rios, A. F.: Water interchange between the Ria of Vigo and the continental shelf, Sci. Mar., 54, 95-100, 1990.

Raven, J., Caldeira, K., Elderfield, H., Hoegh-Guldberg, O., Liss, P., Riebesell, U., Sphepherd, J., Turley, C., and Watson, A.: Ocean acidification due to increasing atmospheric carbon dioxide: Royal Society Policy Document 12/05, 68 pp., 2005.

Ríos, A. F. and Pérez, F. F.: Improvements in potentiometric determinations of the $\mathrm{CO}_{2}$ oceanic system using seawater substandards and $\mathrm{CO}_{2}$ reference materials, Ciencias Marinas, 25, 31-49, 1999.

Ríos, A. F., Pérez, F. F., and Fraga, F.: Water masses in the upper and middle North Atlantic Ocean east of the Azores, Deep-Sea Res. Pt. I, 39, 645-658, 1992.

Ríos, A. F., Velo, A., and Pérez, F. F.: Long-term (1977-1997) measurements of carbon dioxide in the Eastern North Atlantic: evaluation of anthropogenic input, Deep-Sea Res. Pt. II, 48, 22272239, https://doi.org/10.1016/S0967-0645(00)00182-X, 2001.

Rosón, G., Pérez, F. F., Alvarez-Salgado, X. A., and Figueiras, F. G.: Variation of both thermohaline and chemical properties in an estuarine upwelling ecosystem -Ría de Arousa. 1. Time evolution, Estaur. Coast. Shelf Sci., 41, 195-213, doi 10.1006/ecss.1995.0061, 1995.

Rosón, G., Cabanas, J. M., Pérez, F. F., Herrera, J. L., RuizVillarreal, M., Castro, C. G., Piedracoba, S., and ÁlvarezSalgado, X. A.: Evidencias do cambio climático na Hidrografía e a dinámica das Rías e da plataforma galega, Edita: Xunta de Galicia. Consellería de Medio Ambiente e Desenvolvemento Sostible, Evidencias e impactos do cambio climático en Galicia, 287-302, 2009.

Sabine, C. L., Feely, R. A., Gruber, N., Key, R. M., Lee, K., Bullister, J. L., Wanninkhof, R., Wong, C. S., Wallace, D. W. R., Tilbrook, B., Millero, F. J., Peng, T.-H., Kozyr, A., Ono, T., and Rios, A. F.: The oceanic sink for anthropogenic $\mathrm{CO}_{2}$, Science 305, 367-371, 2004.

Sarmiento, J. L. and Gruber, N.: Ocean biogeochemical dynamics, Princeton Univ. Press, 2006.

SCOR-UNESCO: Determination of Photosynthetic Pigments in Seawater, UNESCO, Paris, 1966.
Souto, C., Gilcoto, M., Fariña-Busto, L., and Pérez, F. F. Modeling the residual circulation of a coastal embayment affected by wind-driven upwelling: Circulation of the Ria de Vigo (NW Spain), J. Geophys. Res.-Ocean., 108, 3340, https://doi.org/10.1029/2002JC001512, 2003.

Strickland, J. D. H. and Parsons, T. R.: A practical handbook of seawater analysis, Fisheries Research Board of Canada, Ottawa, Ontario, 1972.

Takeshita, Y., Frieder, C. A., Martz, T. R., Ballard, J. R., Feely, R. A., Kram, S., Nam, S., Navarro, M. O., Price, N. N., and Smith, J. E.: Including high-frequency variability in coastal ocean acidification projections, Biogeosciences, 12, 5853-5870, https://doi.org/10.5194/bg-12-5853-2015, 2015.

Teira, E., Martínez-García, S., Lonborg, C., and Álvarez-Salgado, X. A.: Growth rates of different phylogenetic bacterioplankton groups in a coastal upwelling system, Environ. Microbiol. Rep., 1, 545-554, https://doi.org/10.1111/j.1758-2229.2009.00079.x, 2009.

UNESCO: Background papers and supporting data on the Practical Salinity Scale 1978, UNESCO Tech. Papers in Marine Science, 37, 144 pp., 1981.

Uppström, L. R.: Boron = Chlorinity ratio of deep-sea water from Pacific Ocean, Deep-Sea Res., 21, 161-162, 1974.

Van Heuven, S., Pierrot, D., Rae, J. W. B., Lewis, E., and Wallace, D. W. R.: MATLAB Program Developed for $\mathrm{CO}_{2}$ System Calculations, ORNL/CDIAC-105b. Carbon Dioxide Information Analysis Center, Oak Ridge National Laboratory, U.S. Department of Energy, Oak Ridge, Tennessee, 2011.

Velo, A., Pérez, F. F., Lin, X., Key, R. M., Tanhua, T., de la Paz, M., Olsen, A., van Heuven, S., Jutterström, S., and Ríos, A. F.: CARINA data synthesis project: $\mathrm{pH}$ data scale unification and cruise adjustments, Earth Syst. Sci. Data, 2, 133-155, https://doi.org/10.5194/essd-2-133-2010, 2010.

Velo, A., Cacabelos, J., Pérez, F. F., and Ríos, A.F.: GO-SHIP Software and Manuals: Software packages and best practice manuals and knowledge transfer for sustained quality control of hydrographic sections in the Atlantic. (Version v1.0.0), Zenodo, https://doi.org/10.5281/zenodo.2603122, 2019.

Villacieros-Robineau, N., Zúñiga, D., Barreiro-González, B., Alonso-Pérez, F., de la Granda, F., and Froján, M.: Bottom boundary layer and particle dynamics in an upwelling affected continental margin (NW Iberia), J. Geophys. Res.-Oceans, 124, 9531-9552, https://doi.org/10.1029/2019JC015619, 2019.

Wahl, M., Saderne, V., and Sawall, Y.: How good are we at assessing the impact of ocean acidification in coastal systems? Limitations, omissions and strengths of commonly used experimental approaches with special emphasis on the neglected role of fluctuations, Mar. Freshw. Res., 67, 25-36, https://doi.org/10.1071/MF14154, 2016.

Wolf-Gladrow, D. A., Riebesell, U., Burkhardt, S., and Bijma, J.: Direct effects of $\mathrm{CO}_{2}$ concentration on growth and isotopic composition of marine plankton, Tellus, 51B, 461-476, 1999.

Wooster, W. S., Bakun, A., and McClain, D. R.: The seasonal upwelling cycle along the eastern boundary of the North Atlantic, J. Mar. Res., 34, 131-141, 1976.

Yentsch, C. S. and Menzel, D. W.: A method for the determination of phytoplankton chlorophyll and phaeophytin by fluorescence, Deep-Sea Res., 10, 221-231, 1963. 
Zúñiga, D., Villacieros-Robineau, N., Salgueiro, E., Alonso-Pérez, F., Rosón, G., Abrantes, F., and Castro, C. G.: Particle fluxes in the NW Iberian coastal upwelling system: Hydrodynamical and biological control, Cont. Shelf Res., 123, 89-98, https://doi.org/10.1016/j.csr.2016.04.008, 2016.
Zúñiga, D., Santos, C., Froján, M., Salgueiro, E., Rufino, M. M., De la Granda, F., Figueiras, F. G., Castro, C. G., and Abrantes, F.: Diatoms as a paleoproductivity proxy in the NW Iberian coastal upwelling system (NE Atlantic), Biogeosciences, 14, 1165-1179, https://doi.org/10.5194/bg-14-1165-2017, 2017. 